\title{
Döviz Kurunun Hane Halkı Tüketim Eğlimi Üzerine Etkisi: Türkiye Örneği
}

Elçin AYKAC̣ ALP' - Ali Osman GÜRBÜZ²

Makale Gönderim Tarihi: 26 Șubat 2020

Makale Kabul Tarihi: 17 Eylül 2020

\section{Öz}

Çalıșma Türkiye'de 2003:01-2019:04 döneminde döviz kuru ile tüketici fiyat endeksi arasındaki ilișkiyi ve ilișkinin ürün gruplarının fiyat hareketleri üzerine etkisini incelemektedir. Etkinin yönü ve derecesi dönemler itibariyle farklılașmaktadır. Bu nedenle hem tüm dönem, hem de beșer yıllık dönemler analize tabi tutulmuștur. Analiz yöntemi olarak 394 ürün, 12 mal grubu beșer yıllık periyodlarla korelasyon hesabı yapılarak Dolar, Euro ve Sepet kur ile ilișkinin yönü ve derecesi bakımından incelenmiștir. Aynı dönemler için kurlar ile TÜFE ilișkisi ayrıca VAR analizine tabi tutulmuștur. Bu analiz ile etkinin yönü ve kaç dönem devam ettiği saptanmıștır.

Anahtar kelimeler: Döviz kuru, TÜFE, döviz kuru fiyat etkisi

JEL Sınıflandırması: F3 1, E3 1, C32

Prof. Dr.,İstanbul Ticaret Üniversitesi, İșletme Fakültesi, İktisat Bölümü, e-posta: ealp@ticaret. edu.tr. ORCID ID: https://orcid.org/0000-0001-9076-2102

2 Prof. Dr., İstanbul Ticaret Üniversitesi, İșletme Fakültesi, Bankacılık ve Finans Bölümü, e-posta: ogurbuz@ticaret.edu.tr ORCID ID: https://orcid.org/0000-0003-0230-5839 


\title{
Foreign Exchange Rate Effect on Household Consumption Tendency: The Turkish Case
}

\begin{abstract}
In this study, the relationship between the exchange rate and the consumer price index and the effect of the relationship on the price movements of the product groups were examined in Turkey for the period between 2003:01-2019:04. The direction and degree of impact differ in terms of periods. For this reason, both the entire period and the five-year periods are subjected to analysis. The method of analysis as 394 items, 12 commodity groups for the five-years period by calculating correlations with the dollar, euro and currency basket was examined in terms of direction and impact of the relationship is analyzed. For the same periods, the relationship between the exchange rates and the CPI was also analyzed with VAR models. This method helps to determine the direction and the impact of this relationship and also it shows how long the effect lasted.
\end{abstract}

Keywords: Exchange Rate, CPI, exchange rate pass-through, JEL Classification: F3 1, E3 1, C32

\section{Giriș}

Gelișmekte olan ülkelerde yüksek enflasyon, fiyat hareketlerinde dalgalanma ve fiyat hareketlerinin öngörülebilirliği en önemli iktisadi konulardan biridir. Bu alandaki araștırma konuları da çeșitlilik arz etmektedir. Bizim konuya eğilme sebeplerimiz ise meydana gelen fiyat hareketlerinden tüketicilerin ne șekilde etkilendiği ve politika yapıcıların ne kadar ve nasıl bu etkinin önüne geçebilecekleri konusunun irdelenmesidir. Nitekim makroekonomik değișkenlerin enflasyon üzerine etkisi birçok çalıșmada incelenmiștir. Bu değișkenlerden biri ve bize göre özellikle gelișmekte olan ülkelerde en önemlisi döviz kurudur. Gelișmekte olan ülkelerin döviz kuru dalgalanmalarına karșı kırılgan yapısına bağlı olarak çeșitli makroekonomik değișkenlere de etkisi olmaktadır. Bu yönden incelediğimizde de döviz kuru hareketlerinin tüketici fiyatlarına yansıması literatürde birkaç farklı yoldan açıklanmakta ve ölçülmektedir. Bunlardan ilki ithal edilen malın fiyatına olan doğrudan etkisi ikincisi ise satın alınan nihai ürünün maliyetini etkileyen ithal mallar vasıtası ile aktarım mekanizmasına tabi olan mal fiyatıdır. Bu iki yolun etkisinin 
büyüklüğü ve etkileme zamanı farklılașmaktadır (Chung, Kohler, Lewis, 2011).

Genellikle finansal kriz dönemlerinde döviz kurunda yașanan dalgalanma nedeniyle döviz kurunun ekonomi üzerine etkisi önemli bir araștırma konusu olmuștur. Kur etkisi çeșitli kanallar üzerinden ekonomiyi etkilemektedir. Bu kanallardan biri dıș ticarettir. Dıș ticarette ithal mallarda ülke parası cinsinden yașanan fiyat artıșı enflasyonu etkilemektedir.

İthal malların yaygın kullanımı nihai mal șeklinde ise etki hızlı bir șekilde tüketiciye yansımaktadır. İthal malların girdi olarak kullanımı halinde ise nihai malların fiyatlarına yansıması dolaylı olarak ve daha uzun vadede olmaktadır. İhracat yönünden incelendiğinde ise ülke parasının değer kaybı nedeniyle ihracat cazip hale gelmekte, ihracat artarken ithalat azalmaktadır. Bu durum ülke içindeki mal miktarını görece azalııc etki yaparak fiyatlar genel seviyesinde artıș yaratır (Berument, 2002). Döviz kurundaki artıșın zamanla yarattığı bir diğer etki ise enflasyonda artıș beklentisidir. Yukarıda sayılan nedenlerden birindeki gerçekleșme aynı yoldan enflasyonda artıșının devam edeceği beklentisini olușturmaktadır (Gül ve Ekinci, 2006).

Döviz kurunun fiyatlara yansıması konusunda yapılan çalıșmalarda iki tip model kullanılmıșır. Bunlar ithal malların fiyatlarının neden olduğu enflasyon ve Mark-up modeli ile Phillips eğrisi modelleri kullanılarak incelenen iki basamaklı yöntemdir. Illk yöntemde ithal mal fiyatları geçmiș dönem ihraç mal fiyatları ve geçmiș dönem döviz kuru ile modellenmektedir. İkinci yöntemde ise ilk adımda mark up modeli ile enflasyon; nominal ișgücü maliyeti, enflasyon beklentisi ve ithal mal fiyatı ile modellenmektedir. İkinci adımda ise Phillips eğrisi modeli kullanılmaktadır. Enflasyon; ișsizlik oranı geçmiș değerleri, enflasyon beklentisi ve ithal mal fiyatları ile modellenmektedir. Bu șekilde ölçülen yansıma ithal malların fiyat artıșlarından yani dıș ticaret temelli olması halinde bire bir olmama sebepleri; dıșarıdan alınan üründe satııı firmanın fiyat farklılaștırmasına bașvurma imkanı olması, dünyada diğer firmalar ile rekabet etmesi sebebiyle firmanın fiyat artıșını aynı ölçekte yansıtmaması ve ülke ekonomisindeki dalgalanmanın geçici olduğunun düșünülmesidir.

Diğer taraftan hane halkı tüketiminin fiyat hareketlerinden etkilendiği açıkıı. Fiyat hareketlerinin döviz kurundan hangi yol ile etkilendiğinden ziyade ne ölçüde etkilendiği ve etkilenme dönemlerinin ve etki ağırlığının ne ölçüde farklılașıı̆ı önemlidir. Bu noktadan hareketle, bu çalıșmada bir yandan döviz kurundaki değișim ile hane halkı tüketimini 
doğrudan etkileyen, diğer yandan hane halkı tüketimini belirleyici rol oynayan tüketici enflasyonu ilișkisi incelenmiștir.

Çalıșmanın ikinci bölümünde, literatürde benzer biçimde araștırma sorusuna sahip çalıșmalardan örnekler verilmiștir. Üçüncü bölümde analizlerde kullanmıș olduğumuz veri ve ekonometrik metodoloji hakkında bilgi sunulmuștur. Dördüncü bölümde istatistiksel ve ekonometrik analizler sonucunda elde edilen bulgular ve son olarak da sonuç ve değerlendirme bölümlerine yer verilmiștir.

\section{Literatür Taraması}

Literatürde döviz kuru hareketleri ile hane halkı harcamaları ilișkisini inceleyen çalıșmalar etkinin yönü üzerine farklı sonuçlara ișaret etmektedir. Dolayısıyla literatürde uygulanan yöntem, ülke ve incelenen zamana bağlı olarak kur hareketlerinin enflasyonu etkilediği, enflasyonun kur hareketlerini etkilediği, ikisi arasında ilișki olmadığı ve ilișkinin çift yönlü olduğuna dair sonuçlar bulunmaktadır.

Türkiye için yapılmıș yakın dönem çalıșmalardan biri olan Karahan (2017) çalıșmasında döviz kurunun enflasyon hedeflemesi rejimi öncesi ve sonrasında enflasyona etkisi incelenmiștir. Çalıșma 19952000 dönemi ile 2006-2014 dönemini ayırarak incelemiștir. Arada kalan 2000-2006 dönemi geçiș dönemi olması sebebiyle analiz dıșı bırakılmıștır. Analizde çalıșmamıza benzer biçimde sistem modeli yapısında olan ancak uzun dönem analizinin de yapılmasını sağlayan VEC modeli kullanılmıștır. Elde edilen bulgular, önceki periyodun aksine, enflasyon hedeflemesi rejimi döneminde düșük ve istikrarlı enflasyon oranı döviz kurunun enflasyona yansımasını azaltmıșıır. Bunun sebebi, enflasyon hedeflemesi rejimi döneminde olușan șeffaflık ve düșük enflasyon ile birlikte gelen düșük risk primi olabilir.

Türkiye üzerine yapılmıș bir çalıșma olmamakla birlikte, çalıșmamız ile araștırma sorusunun benzerliği, tek bir ülke üzerine yapılmıș bir çalıșma olması ve benzer analiz metotlarının kullanımı nedeniyle Bonsu ve Muzindutsi (2017) çalıșması önem arz etmektedir. Gana için hane halkı tüketim harcamaları ve etkileyen bileșenler incelenmiștir. Bonsu ve Muzindutsi (2017) çalıșması 1961 - 2013 dönemini kapsayan yıllık veriler kullanılarak eștümleșme yaklașımı uygulamıștır. Bu çalıșma ile benzer șekilde GSYIH, tüketici fiyatları ve reel döviz kuru ile VAR analizi uygulanmıștır. Sonuç olarak hane halkı tüketiminin büyüme ve gelir dıșında döviz kurundan da etkilendiği bulgusu elde edilmiștir. Hatta poli- 
tika çıkarsamalarında ülkede yerli mal tüketiminin özendirilmesinin yerli paranın değeri bakımından önemi irdelenmiștir.

Chung, Kohler, Lewis (2011) çalıșmalarında Avustralya'da enflasyon hedeflemesi döneminde döviz kurunun fiyat yansımasını incelemiș, ve ülkeler arası ticarete konu olan perakende mal fiyatlarına özellikle etkisi olduğunu göstermiștir. Çalıșmadaki temel argümanlardan biri internet vasıtasıyla satın alıcıların düșük fiyat araștırmasının ek maliyete katlanmaksızın yapılabiliyor olması nedeniyle döviz kurunun fiyat yansımasının görülebildiğini öne sürmektedir. Ayrıca döviz kurunun ithal mal fiyatlarını daha hızlı etkilediği, buna karșılık yurt içi fiyatlara ve tüketici enflasyonuna yansımasının daha yavaș ve düșük seviyede olduğunu görmüșlerdir. Chung vd. (2011) çalıșmasında literatürde yer alan enflasyon hedeflemesi rejiminin uygulanması halinde döviz kuru dalgalanmalarının fiyatlara olan etkisinin daha yavaș olduğu üzerinde de durulmuștur. Bunun bir nedeni de enflasyon hedefleme rejimi olması halinde beklentilerin güçlü olması ve dalgalanmanın geçici olduğuna inanılmasıdır. Hızlı yansımanın var olma sebepleri de șokların geçici olduğuna inanılması, teknolojik gelișmeye bağlı olarak fiyat değișikliklerinin hızlı ve maliyetsiz bir șekilde yapılabilir hale gelmesi ve tüketicinin interneti de kullanarak daha düșük fiyatlı ürünler konusunda bilgi edinme șansının olması sebebiyle fiyat düșüșlerini tüketiciye hızlıca yansıtabilmeleri gösterilmiștir.

Gül, Ekinci (2006) çalıșması nominal döviz kuru ile tüketici fiyatları arasındaki nedensellik ilișkisini incelemiștir. Çalıșma uzun dönemde nedensellik ilișkisinin varlığını ancak ilișkinin döviz kurundan enflasyona doğru tek yönlü olduğu sonucuna ulașmıștır. 1984-2003 dönemini kapsayan çalıșmada Johansen eștümleșme testi ile Granger nedensellik analizi uygulanmıștır.

Berument (2002) çalıșması Türkiye için reel döviz kuru ile enflasyon dinamiği ilișkisini incelemiștir. Çalıșmada döviz kuru ile tüketici fiyatları ve toptan eșya fiyatları ayrı ayrı incelenmiștir. Çalıșma döviz kuru ile TEFE ilișkisini Tarım, Maden, Imalat ve Enerji sektörleri toptan eșya fiyat arıșları ile incelemiș, TÜFE ilișkisi için ise tüketici fiyat endeksinin 7 alt kategorisindeki fiyat artıșlarını analize tabi tutmuștur. Bu yedi alt kategori Konut, Kültür, Ulaștırma, Sağlık, Ev, Gıda ve Giyim kategorileridir. Elde edilen bulgular reel döviz kurunun toptan eșya fiyatlarını tüketici fiyatlarından daha fazla etkilediği yönündedir. Ayrıca reel kurun imalat sanayiini en yüksek, tarım sektörünü de en az etkilediği yönünde sonuç elde edilmiștir. 
Bu bölümün bașında da değinildiği üzere, sadece Türkiye ekonomisi üzerine yapılan ve farklı dönemlerde farklı sonuçların olduğu çok sayıda çalıșma mevcuttur. Literatür taramasında, bu alanda yapılmıș olan farklı bakıș açılarını ortaya koyabilmek için bașlıca çalıșmalara yer verilmiștir. Ancak bizim bakıș açımızda, döviz kurunun oynaklığının yüksek ve düșük olduğu dönemlerde hane halkı tüketimine yaptığı etkinin de incelenmesi temel araștırma konularından biridir.

\section{Veri ve Metodoloji}

\section{a. Veri}

Çalıșmada 2003:01 - 2019:04 yılları arasında aylık enflasyon rakamları ile döviz kuru ilișkisi incelenmiștir. Bu dönemler arasında enflasyon hesabında kullanılan mal kalemlerinin sabit tutulabilmesi açısından bu dönemlerde sepete giriș yapan ve çıkan ürünler incelenmiș, 2015 yılı sonrasında sepete eklenen ürünler dikkate alınmamıștır. Toplam 394 mal kalemi üzerinden hesaplamalar yapılmıștır. Temel hedef döviz kurundaki değișimin tüketim üzerine yansımasını görmek olduğu için 394 mal kalemi üzerinden değil, ürün grupları ile döviz kuru arasındaki ilișki incelenmiștir.

Enflasyon sepetinde 12 mal grubu, 418 kalem mal mevcuttur. Döviz kurundaki değișimin bu sepetteki sürekliliği esas alınarak, seçilmiș 394 ürün ve 12 mal grubunun fiyat seviyesine yansımaları korelasyon analizi ile incelenmiștir.

İnceleme hem Dolar, hem Euro, hem de sepet kur dikkate alınarak yapılmıștır. Ayrıca, dönemin tamamı ve 5'er yıllık periyodlar halinde korelasyon hesaplanmıștır. Döviz kuru hareketinin enflasyona yansıması sadece cari dönem için değil aynı zamanda bir ay sonrası ve 3 ay sonrasına etkisi de incelenmiștir. Incelenen dönemlerde ortalama değerler așağıda belirtilmiștir.

Tablo 1. İncelenen Dönemlerde Verilere illișkin Ortalama Değerler

\begin{tabular}{|l|c|c|c|c|}
\hline Dönem & USD & Euro & Sepet Kur & TÜFE \\
\hline $2003-2008$ & 1,41 & 1,75 & 1,58 & 0,73 \\
\hline $2008-2013$ & 1,57 & 2,15 & 1,86 & 0,64 \\
\hline $2013-2017$ & 2,71 & 3,20 & 2,96 & 0,72 \\
\hline $2018-2019$ & 5,01 & 5,83 & 5,42 & 1,42 \\
\hline $2003-2019$ & 2,40 & 2,96 & 2,68 & 0,76 \\
\hline
\end{tabular}




\section{b. Metodoloji}

Çalıșmada kullanılan verilere yapılmıș olan temel analiz korelasyon analizi ile bașlamaktadır. Elde edilen bulgular da bu analiz ıșığında șekillenmektedir. Ancak bizi sonuca götüren bulguları açıkça ortaya koyan bu analiz, var olan karmașık ilișkiler bütününde bir hataya yer vermemek adına ekonometrik zaman serileri analizleri ile desteklenmektedir.

Illk așamada kullanılmakta olan zaman serilerinin uzun dönem ilișkilerinin incelenebilmesi adına ilk kural olan birim kök analizleri yapılmıșıır. İkinci așamada farklı dönemlerde farklı yapılar olduğunun saptanması sebebiyle alt dönemler için de bu analizler uygulanmıștır. Tüm birim kök analizlerinden sonra enflasyon ile döviz kuru arasında bu dönemlerde var olan uzun dönem denge ilișkisi eștümleșme analizi ile incelenmiștir.

Ara dönemlerde sağlıklı zaman serisi analizleri yapılabilmesi için yeterli veri kısıııı sağlayan dönemler 2003-2008, 2008-2013, 20132017 dönemleri ve tüm dönemin söz konusu olduğu 2003-2019 dönemleridir. Çalıșmada incelemiș olduğumuz 2018-2019 dönemi korelasyon analizi bakımından anlamlı sonuç üretmekle birlikte ekonometrik açıdan analiz yapma koșullarını veri sayısııın az olması sebebiyle sağlamamaktadır.

Illk etapta uygun ekonometrik analiz yönteminin saptanması açוsından birim kök analizi uygulanmıștır. Analizler sonuçlarda önemli sapmalar olmaması sebebiyle Augmented Dickey Fuller (ADF), ve Phillips Perron (PP) birim kök testleri ile sınırlı tutulmuștur. Dönemler bakımından, hem tüm dönem hem de alt dönemler ayrı ayrı birim kök analizine tabi tutulmuș, sonrasında ise Vektör Otoregresif Modeller (VAR) ile analiz edilmiștir.

\section{Augmented Dickey - Fuller Birim Kök Testi}

Seride birim kökün varlığını belirlemek için kullanılan testlerin en tanınmıșları Dickey-Fuller (DF) ve Geliștirilmiș Dickey-Fuller (ADF) testleridir.

$$
y_{t}=\mathrm{r} y_{t \square 1}+\mathrm{e}_{t}
$$

șeklinde olușturulan bir otoregresif modelde $y_{t}$ serisinin birim kök içermesi $|r|=1$ olması anlamına gelmektedir. DF (1979) tarafından tablolaștırılan kritik değerler üç genel model için olușturulmuștur. DF testi 
hata terimlerinin saf hata terimi sürecine sahip olduğunu varsaymaktadır. Serisel korelasyon olması halinde EKK tahminlerinin sağlıklı olması için test geliștirilmiș ve Genișletilmiș Dickey Fuller (ADF) testi olarak adlandırılmıștır. ADF testi denklemleri sabit terim içeren, içermeyen ve sabit terim ile trend terimi içeren modeller șeklinde olușturulmuștur. Bu modeller içinde $t$ tablo değerlerinden yararlanılır.

\section{Phillips ve Perron Birim Kök Testi}

Phillip ve Peron testi, Phillips'in 1987 yılında yazdığı makalesinde incelenen durumların daha da genișletilmesinden doğan bir birim kök testidir. Test uygulamada oldukça önemli olan iki durumu analize katmaktadır. Birincisi, bir yığılımın var olması, ikincisi ise hem yığılım hem de doğrusal trendin olmasıdır. Bu testte de üç farklı regresyon modelinden biri üzerine kurulur. Ancak bu testlerin farkı trend teriminin merkezileșmesidir (Phillips ve Perron, 1988).

\section{Vector Autoregressive Model (VAR)}

VAR modelleri zaman serilerinde sistem çözümleri için kullanılan tüm değișkenlerin içsel olarak sistemde yer aldığı modellerdir. Sistemde tüm değișkenlerin gecikmeli halleri kullanılır. Iki değișkenli bir VAR modeli için așağıdaki denklemler yazılabilir:

$$
\begin{aligned}
& Y_{t}=\alpha_{1}+\sum_{i=1}^{n} \alpha_{2 i} Y_{t-i}+\sum_{j=1}^{n} \alpha_{3 j} X_{t-j}+u_{1 t} \\
& X_{t}=\beta_{1}+\sum_{i=1}^{n} \beta_{2 i} Y_{t-i}+\sum_{j=1}^{n} \beta_{3 j} X_{t-j}+u_{2 t}
\end{aligned}
$$

Bu değișkenlerin her birinin düzey hallerinin durağan olması halinde sistemde gecikmeli değerlerinin birbirine etkilerini elde edilmektedir. $u_{1 t}$ ve $u_{2 t}$ hata terimleri kendi geçmiș değerleri ve bağımsız değișkenler ile ilișkisizdir. Bu modeller ile elde edilen bir diğer bilgi seti de etki-tepki analizi ve varyans ayrıștırma faktörüdür. Bu analizler vasıtasıyla her bir değișkende meydana gelen bir șokun diğer değișkenlerde yarattığı etkiyi analiz etmek mümkün olmaktadır.

\section{Bulgular}

Çalıșmada uygulanan ilk analiz korelasyon analizidir. Tablo 1'de ortalamaları verilmiș olan kur-enflasyon verilerinin her mal grubu için ( $t$ ), $(t+1)$ ve $(t+3)$ döneminde korelasyonları hesaplanmıștır. 
Tablo 2'de tüm analiz döneminde (2003-2019) döviz kurları ile fiyat artıșı arasındaki korelasyon raporlanmıștır. Hane halkı tüketiminde fiyat hareketinin dolar ile cari ayda korelasyonu incelendiğinde ürünlerin yaklașık \%49'u \%90'ın üzerinde ilișki göstermiștir. Ürünlerin yaklașık $\% 47$ 'si ise \%50-90 arası ilișkili çıkmıștır. Fiyat hareketi \%50'nin alında ilișkili çıkan ürün ise 394 ürünün yaklașık \% 1,5 kadarıdır.

12 ürün grubunun cari ay döviz kuru korelasyonları incelendiğinde sepetin \%23,29'unu olușturan gıda ve alkolsüz içecekler grubunun \%99'u döviz kuru ile \%50 üzeri ilișkili çıkmıștır. Diğer gruplarda da durum benzer șekildedir. Sağlıkta bu oran \%79, haberleșmede \%85 diğer tüm kategorilerde \%50 üzerinde korelasyon \%98 ve üzerindedir.

Benzer oranlar Euro ve sepet kur için de elde edilmiștir. Oranlarda önemli fark olmamakla birlikte Euro ve sepet kur için hesaplanan korelasyonlarda \%90 üzeri ilișkili çıkan ürünlerin sepetin yaklașık \%54'ü olduğu görülmüștür. Bu așamada ilk akla gelen cari ay ilișkisinin yanı sıra dövizdeki artıșın bir sonraki ay fiyatları ile ve üç ay sonraki fiyatları ile ilișkisinin incelenmesidir. Bu katsayılar da hesaplanarak sırayla raporlanmıștır.

Tablo 3 ve Tablo 4 döviz kurundaki değișimin bir ay sonraki fiyatlar ve üç ay sonraki fiyatlar ile olan ilișkileri ortaya koymaktadır. Cari ay için hesaplanan korelasyonlar ile neredeyse tamamen aynı sonuçlar elde edilmiștir. Bu üç tablo analiz döneminin tümünü kapsamaktadır; ancak beșer yıllık periyodlar ile incelendiğinde döviz kurunun etkisi ve yansıması farklılașmaktadır.

Tablo 5 2003-2007:12 dönemi için hesaplanmıș olan cari ay döviz kuru TÜFE korelasyonlarını göstermektedir. Tablodan da görülebileceği üzere elde edilen ilișkiler \%50 ve üzeri korelasyon göstermemektedir. Döviz ile TÜFE ilișkisi \%90'a yakın ürün ve ürün grubunda ilișkinin negatif olduğu görülmektedir.

Elde edilen ilișkiler dolar ile tüm mal grupları arasında negatif ilișkili, Euro ile \%50'nin altında ilișkili çıkmıștır. Tablo 6 ve 7'de bir ay ve üç ay sonrası için hesaplanan korelasyonlar Tablo 5 ile benzerlik göstermekle birlikte negatif korelasyon gösteren ürün miktarı \%90 seviyesine yükselmiștir.

İncelenen dönem içinde 2003-2007:12 dönemi sonuna doğru önemli bir global kriz barındırmasına rağmen ortaya çıkan ilișki, dönemin tümünden de 2008 sonrası için incelenen dönemlerden de farklıdır. 
Bu dönemin özelliği hem enflasyonun hem de döviz kurunun nispeten yatay seyir izlediği ve piyasadaki güvenin yüksek olduğu, dalgalanmaların geçici olduğuna inanıldığı bir dönemdir.

Tablo 8, 2008-2012 dönemini kapsayan döviz kuru TÜFE ilișkilerini içermektedir. Elde edilen bulgular cari ay ilișkisinde \%77-80 bandında ürün grubu ile döviz kurları arasında \%50-90 aralığında korelasyona ișaret etmektedir. Ürünlerin \%12 ila \%18 aralığında bir kısmının ise \%50'nin altında döviz kuru fiyat korelasyonuna sahip olduğunu göstermektedir.

Tablo 9 ve 10 döviz kuru ile fiyat ilișkisinin bir ay ve üç ay ileriye etkisinin incelendiği tablolardır. Bu tablolar da Tablo 8 ile benzer ilișkiye ișaret etmektedir.

Tablo 11, 2013-2017 döneminde döviz kurlarındaki artıșın tüketici enflasyonuna ve alt kalemlerine yansımasını göstermektedir. Bu dönem analiz dönemi içinde döviz kurundaki artıșın hızlandığı ve paralel olarak enflasyonda da önemli bir artıș olduğu dönemdir. Hesaplanan korelasyonlar incelendiğinde \%50 - \%90 arasında korelasyon gösteren ve \%90'ın üzerinde korelasyon gösteren kalemler sepetin neredeyse tamamını olușturmaktadır. Cari ayda döviz kurunda yașanan artıșın yansıması alkollü içecekler ve tütün kategorisine \%100 olmuștur. Beklenti dahilinde olan bu oranı lokanta ve oteller (ürünlerin tamamında \%50 üzeri korelasyon hesaplanmıștır), ev eșyası (ürünlerin \%98'inde \%50 üzeri korelasyon hesaplanmıștır), giyim ve ayakkabı (ürünlerin \%92'sinde \%50 üzeri korelasyon hesaplanmıștır), eğlence ve kültür (ürünlerin \%92'sinde \%50 üzeri korelasyon hesaplanmıștır) kategorileri takip etmiștir. Diğer kalemlerde de yüksek olan korelasyon tek bir kategori (Eğitim) hariç \%70'in altına inmemiștir. Bu bulgular Dolar, Euro, sepet kur için ve Tablo 12 ve $13^{\prime}$ de bir ay sonrası ve üç ay sonrası için hesaplanan korelasyonlar için de geçerlidir.

Tablo 14, Tablo 15 ve 16, 2018 yılı sonrası için hesaplanmıștır. Döviz kurundaki ve enflasyondaki artıșın gittikçe artığı dönemde cari ay etkilerinin nispeten daha yüksek olduğu görülmektedir. Önceki tablolarda incelenen dönem aralıklarında bir ay ve üç ay sonrasında etkinin bazı kalemlerde arttığı ya da aynı kaldığı görülmekteyken 2018 sonrasında döviz kuru ile tüketici enflasyonunun çoğu kalemde ve toplamda korelasyonunun daha yüksek olduğu görülmektedir. Bu gösterge tek bașına yeterli olmamakla birlikte 2018 sonrasında gerçekleșen dalgalanmanın geçici olmadığını düșünerek döviz kurundaki artıșın cari 
ayda fiyatlara yansıtıldığını göstermektedir. Cari dönemde daha düșük korelasyon görülen ve üç ay sonra artıș gösteren tek ürün grubu giyim ve ayakkabı olmuștur, diğer ürün grupları ya artmıș ya da aynı kalmıștır. Bu üç tabloda önceki dönemlerden farklılașan bir diğer husus ise, diğer dönemlerde önemli ölçüde döviz ile paralel hareket eden iki sektörde bu ilișkinin azalması ve hatta etkisini kaybetmesidir. Aradaki ilișkinin neredeyse tamamen kaybolduğu grup alkollü içkiler ve tütün grubudur. Döviz ile korelasyonu \%50 üzerinde olan ürün miktarı bu grubun içinde \%8'dir. Değișiklik gösteren diğer bir mal grubu ise giyim ve ayakkabıdır. Bu grupta \%50 üzerinde korelasyon gösteren ürün, gruptaki ürünlerin yalnızca \%56'sı olmuștur.

Bu ilișki analizinden sonra, kısa dönem dinamikleri konusunda daha ayrıntılı ve yorum yapmaya elverișli, güvenilir bilgi sunacak analiz yöntemi VAR modelleridir. Yukarıda yorumlarına yer verilmiș olan tüm analiz dönemleri için VAR modeli tahmin edilmiștir.

Döviz kurunda meydana gelen kısa dönemli değișimlerin enflasyon üzerine etkisini incelemek amacı ile kurulmuș olan VAR modelleri sonuçları ve bu modellerin uygulanmasında ilk adım olan önkoșul niteliğindeki Birim kök test sonuçları așağıda sunulmuștur.

Tablo 17. Birim Kök Test Sonuçları

\begin{tabular}{lcc}
\hline & ADF & PP \\
\hline 2003:01-2019:04 & \\
\hline TUFE & $-8.484(3)$ & $-10.13(17)$ \\
USD & $-12.246(0)$ & $-12.173(4)$ \\
EURO & $-12.764(0)$ & $-12.747(8)$ \\
SEPET & $-12.380(0)$ & $-12.296(7)$ \\
\hline 2003:01-2007:12 & \\
\hline TUFE & $-7.171(2)$ & $-7.854(39)$ \\
USD & $-7.109(0)$ & $-7.173(6)$ \\
EURO & $-7.044(0)$ & $-7.176(10)$ \\
SEPET & $-7.020(0)$ & $-7.104(8)$ \\
\hline
\end{tabular}

\begin{tabular}{lcc}
\hline & \multicolumn{1}{c}{ ADF } & PP \\
\hline 2008:01-2012:12 \\
\hline TUFE & $-6.158(0)$ & $-6.006(6)$ \\
USD & $-6.673(0)$ & $-6.673(0)$ \\
EURO & $-6.631(0)$ & $-6.635(3)$ \\
SEPET & $-6.277(0)$ & $-6.305(1)$ \\
\hline 2013:01-2017:12 & \\
\hline TUFE & $-5.303(3)$ & $-7.136(2)$ \\
USD & $-7.250(0)$ & $-7.298(8)$ \\
EURO & $-8.338(0)$ & $-8.359(6)$ \\
SEPET & $-7.894(0)$ & $-8.154(9)$ \\
\hline
\end{tabular}

ADF - PP testleri kritik değerleri, 2003:01-2019:04 dönemi için; -3.46(\%1), -2.87(\%5), -2.57(\%10), 2003:012007:12 dönemi için, -3.54(\%1), -2.91(\%5), -2.59(\%10), 2008:01-2012:12 dönemi için, $-3.54(\% 1)$, $-2.91(\% 5),-2.59(\% 10), 2013: 01-2017: 12$ dönemi için,-3.54(\%1), $-2.91(\% 5),-2.59(\% 10)$. 


\section{Tablo 18: VAR Modeli Gecikme Uzunluğu Seçimi}

\begin{tabular}{llll}
\hline Değișken & $\begin{array}{l}\text { VAR Modeli } \\
\text { (Gecikme uzunluğu) }\end{array}$ & Değișken & $\begin{array}{l}\text { VAR Modeli } \\
\text { (Gecikme uzunluğu) }\end{array}$ \\
\hline 2003:01-2019:04 & & $\mathbf{2 0 0 8 : 0 1 - 2 0 1 2 : 1 2}$ & \\
TUFE $=>$ USD & $\operatorname{VAR}(4)$, & TUFE $=>$ USD & $\operatorname{VAR}(2)$, \\
TUFE = > EURO & $\operatorname{VAR}(4)$, & TUFE $=>$ EURO & $\operatorname{VAR}(2)$, \\
TUFE $=>$ SEPET & $\operatorname{VAR}(4)$, & TUFE $=>$ SEPET & $\operatorname{VAR}(2)$, \\
$\mathbf{2 0 0 3 : 0 1 - 2 0 0 7 : 1 2}$ & & $\mathbf{2 0 1 3 : 0 1 - 2 0 1 7 : 1 2}$ & \\
TUFE = > USD & $\operatorname{VAR}(3)$, & TUFE $=>$ USD & $\operatorname{VAR}(4)$, \\
TUFE = > EURO & $\operatorname{VAR}(3)$, & TUFE $=>$ EURO & $\operatorname{VAR}(4)$, \\
TUFE $=>$ SEPET & $\operatorname{VAR}(3)$, & TUFE $=>$ SEPET & $\operatorname{VAR}(4)$, \\
\hline
\end{tabular}

\section{VAR modeli Analiz Sonuçları}

2003-2019:04 dönemi için elde edilen VAR modeli dört gecikme ile kurulmuș ve elde edilen katsayılar așağıda verilmiștir. Modeller incelendiğinde ilk modelin dolar kurundaki artıșın enflasyona etkisinin pozitif olduğu ve yakın dönem etkisinin yüksek olduğunu göstermektedir. Bu sonuca varılma sebebi döviz kurunun (t-1) dönemindeki etkisi 0.05, (t-2) dönemindeki etkisinin 0.02, (t-3) dönemindeki etkisi 0.01, (t-4) dönemindeki etkisinin 0.02 olmasından kaynaklanmaktadır.

$$
\begin{aligned}
& \text { DTUFE }=0.7299+0.302 \text { DTUFE }_{t-1}-0.287 \text { DTUFE }_{t-2}+0.128 \text { DTUFE }_{t-3}-0.205 \text { DTUFE } E_{t-4} \\
& +0.052 \text { DUSD }_{t-1}+0.023 \text { DUSD }_{t-2}-0.012 D U S D_{t-3}+0.022 D U S D_{t-4} \\
& \text { DUSD }=1.165-0.401 \text { DTUFE }_{t-1}-0.061 \text { DTUFE }_{t-2}-0.402 \text { DTUFE }_{t-3}+0.33 \text { DTUFE } E_{t-4} \\
& +0.137 \text { DUSD }_{t-1}-0.075 \text { DUSD }_{t-2}+0.037 D \text { USD }_{t-3}-0.0087 \text { DUSD }_{t-4}
\end{aligned}
$$

VAR modeli sonucunda elde edilen Etki-Tepki analizi sonuçları Șekil 1'de verilmiștir. Illk grafikte görülen dolar kurunda meydana gelen 1 standart sapmalık șok enflasyona pozitif etki yapmakta ve bu etkinin ikinci dönemde maksimum seviyeye çıktığı görülmektedir. Meydana gelen șokun pozitif etkisi dördüncü dönemde yok olmaktadır. Dolayısıyla dolar kurunda yașanan bir șokun diğer koșullar sabit ve bir defalık olduğu durumda 4 ay sonunda yok olacağını bize göstermektedir. 
Response to Cholesky One S.D. Innovations \pm 2 S.E.

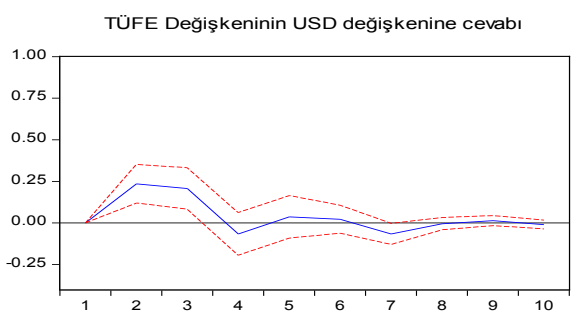

USD Değişkeninin TÜFE değişkenine cevabı

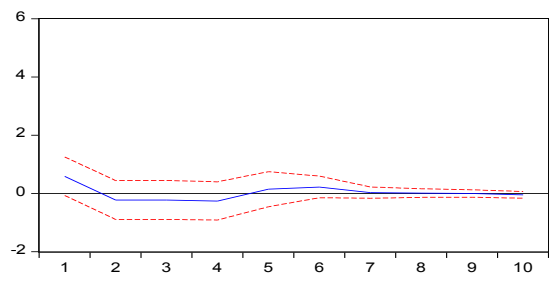

\section{Șekil 1: 2003-2019:04 Dönemi İçin Dolar Kurunun Ełki - Tepki Analizi Sonuçları}

Euro ile enflasyon arasındaki ilișkinin 2003-2019:04 dönemi için incelenmiș olduğu VAR modeli dört gecikme ile kurulmuș ve elde edilen katsayılar așağıda verilmiștir. Modeller incelendiğinde ilk modelin euro kurundaki artıșın enflasyona etkisinin pozitif olduğu ve dolar kurundakine benzer șekilde yakın dönem etkisinin yüksek olduğunu göstermektedir. Bu sonuca varılma sebebi euro kurunun (t-1) dönemindeki etkisinin 0.065, (t-2) dönemindeki etkisinin 0.029, (t-3) dönemindeki etkisi $0.013,(t-4)$ dönemindeki etkisinin 0.03 olmasından kaynaklanmaktadır.

$$
\begin{aligned}
\text { DTUFE }= & 0.718+0.271 \text { DTUFE }_{t-1}-0.256 \text { DTUFE }_{t-2}+0.103 \text { DTUFE }_{t-3}-0.191 \text { DTUFE }_{t-4} \\
& +0.065 \text { DEURO }_{t-1}+0.0285 \text { DEURO }_{t-2}-0.0125 \text { DEURO }_{t-3}+0.029 \text { DEURO }_{t-4} \\
\text { DEURO } & =1.48-0.627 \text { DTUFE }_{t-1}+0.24 D T U F E_{t-2}-0.68 \text { DTUFE }_{t-3}+0.155 \text { DTUFE }_{t-4} \\
& +0.104 \text { DEURO }_{t-1}-0.071 \text { DEURO }_{t-2}-0.0668 \text { DEURO }_{t-3}+0.044 \text { DEURO }_{t-4}
\end{aligned}
$$

Euro kuru ile tahmin edilen VAR modeli sonucunda elde edilen Etki-Tepki analizi sonuçları Șekil 2'de verilmiștir. İlk grafikte euro kurunda meydana gelen 1 standart sapmalık șokun enflasyona etkisinin pozitif olduğu ve bu etkinin dolar kurunda olduğu gibi ikinci dönemde maksimum seviyeye çıktığı, meydana gelen șokun pozitif etkisinin dördüncü dönemde yok olduğu görülmektedir. 
Response to Cholesky One S.D. Innovations \pm 2 S.E.

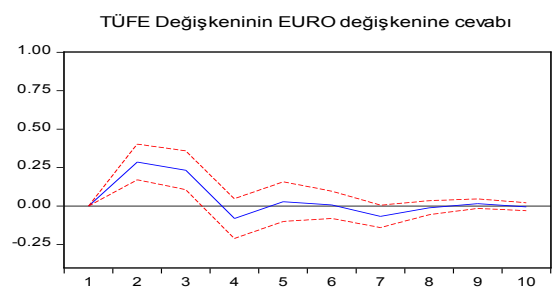

EURO Değişkeninin TÜFE değişkenine cevabı

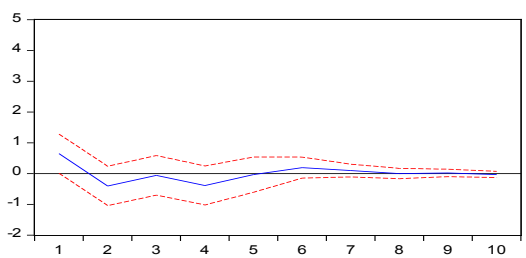

Șekil 2: 2003-2019:04 Dönemi İçin Euro Kurunun Ełki - Tepki Analizi Sonuçları

2003-2019:04 dönemi için sepet kur ile elde edilen VAR modeli dört gecikme ile kurulmuș ve elde edilen katsayılar așağıda verilmiștir. Modeller incelendiğinde ilk modelin sepet kurdaki artıșın enflasyona etkisinin benzer șekilde pozitif olduğu ve yakın dönem etkisinin yüksek olduğunu göstermektedir.

$$
\begin{aligned}
\text { DTUFE }= & 0.721+0.277 \text { DTUFE }_{t-1}-0.268 \text { DTUFE }_{t-2}+0.108 \text { DTUFE }_{t-3}-0.194 \text { DTUFE }_{t-4} \\
& +0.0657 \text { DSEPET }_{t-1}+0.0289 \text { DSEPET }_{t-2}-0.0134 \text { DSPET }_{t-3}+0.03 \text { DSEPET }_{t-4} \\
\text { DSEPET }= & 1.315-0.511 \text { DTUFE }_{t-1}+0.124 \text { DTUFE }_{t-2}-0.581 \text { DTUFE }_{t-3}+0.24 D T U F E_{t-4} \\
& +0.132 \text { DSEPET }_{t-1}-0.081 \text { DSEPET }_{t-2}-0.029 \text { DSEPET }_{t-3}+0.03 \text { DSEPET }_{t-4}
\end{aligned}
$$

Sepet kur ile tahmin edilen VAR modeli sonucunda elde edilen Etki-Tepki analizi sonuçları Șekil 3'de verilmiștir. Illk grafikte Sepet kurda meydana gelen 1 standart sapmalık șokun enflasyona etkisinin pozitif olduğu ve bu etkinin dolar ve Euro kurunda olduğu gibi ikinci dönemde maksimum seviyeye çıktığı, meydana gelen șokun pozitif etkisinin dördüncü dönemde yok olduğu görülmektedir.

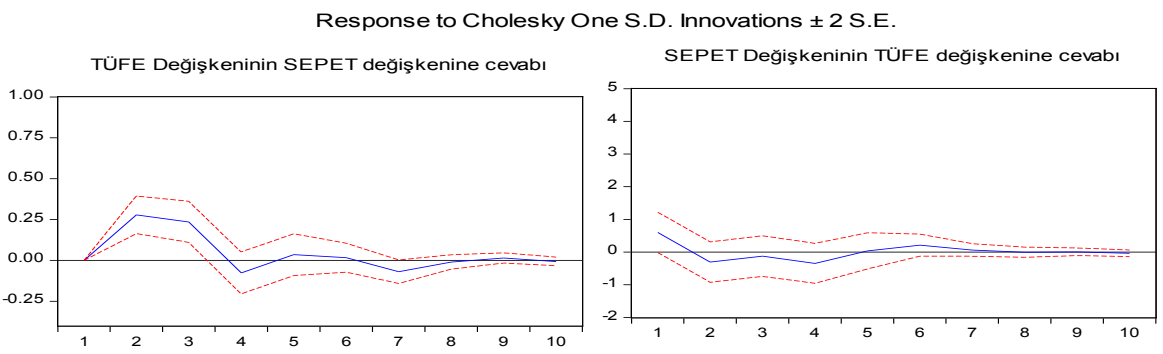

Șekil 3: 2003-2019:04 Dönemi İçin Sepet Kur Ełki - Tepki Analizi Sonuçları

2003-2007:12 dönemi için elde edilen VAR modeli üç gecikme ile kurulmuș ve elde edilen katsayılar așağıda verilmiștir. Modeller ince- 
lendiğinde ilk modelin dolar kurundaki artıșın enflasyona etkisinin ilk dönemde negatif ikinci dönemde pozitif olduğu görülmüștür. Tüm dönemin birlikte incelendiği modeller ile benzer olarak yakın dönem etkisi görece daha büyüktür. Etkinin ișaretinin farklı olması da bu dönemin yapısından kaynaklanmaktadır. 2003-2008 yılları arasında tablo 1'de de görüleceği üzere hem kur ortalama değerlerinin düșük, hem de son döneme nazaran düșük enflasyon dönemidir. Daha da önemlisi enflasyonun düșüș sürecinde hareket ettiği, merkez bankası politikalarının gizli ve açık enflasyon hedeflemesi olduğu dönemlerdir. Bu dönemlerde dolar kurunda artıs i ilk etapta negatif ikinci dönemde pozitif etki yaratması beklentilerin etkinliğine ișaret etmektedir.

$$
\begin{aligned}
\text { DTUFE }= & 0.86+0.297 \text { DTUFE }_{t-1}-0.056 \text { DTUFE } \\
& -0.0214 D U S D_{t-2}+0.0116 \text { DUSD } D_{t-2}-0.00816 \text { DUSD } D_{t-3} \\
\text { DUSD }= & 0.822+0.308 D T U F E_{t-1}-0.747 D T U F E_{t-2}-1.446 D T U F E_{t-3} \\
& +0.072 D U S D_{t-1}-0.145 D U S D_{t-2}-0.0266 D U S D_{t-3}
\end{aligned}
$$

VAR modeli sonucunda elde edilen Etki-Tepki analizi sonuçları Șekil 4'te verilmiștir. İlk grafikte görülen dolar kurunda meydana gelen 1 standart sapmalık șokun enflasyona önce negatif etki yaptığı, bu etkinin ikinci dönemde maksimum seviyeye çıktığı görülmektedir. Meydana gelen șokun negatif etkisi üçüncü dönemde yok olmaktadır.

Response to Cholesky One S.D. Innovations \pm 2 S.E.

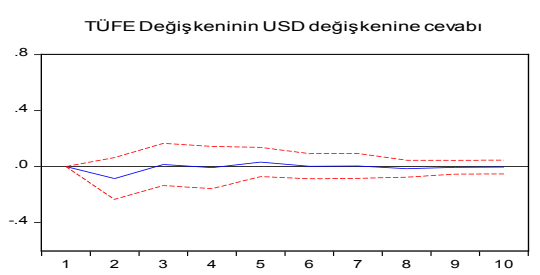

USD Değiş keninin TÜFE değiş kenine cevab

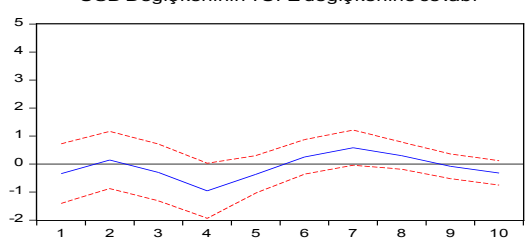

\section{Șekil 4: 2003-2007:12 Dönemi İçin Dolar Kuru Etki - Tepki Analizi Sonuçları}

Euro ile Enflasyon arasındaki ilișkinin 2003-2007: 12 dönemi için incelenmiș olduğu VAR modeli üç gecikme ile kurulmuș ve elde edilen katsayılar așağıda verilmiștir. Dönemin etkisi bir önceki modellerde açıklanmıștı. Benzer șekilde dolar kuruna paralel sonuçlar elde edilmiștir. Modeler incelendiğinde ilk modelin euro kurundaki artıșın enflasyona etkisinin negatif olduğu görülmektedir. 


$$
\begin{aligned}
\text { DTUFE }= & 0.845+0.3245 \text { DTUFE }_{t-1}-0.0954 \text { DTUFE }_{t-2}-0.447 \text { DTUFE }_{t-3} \\
& -0.0128 \text { DEURO }_{t-1}+0.0229 \text { DEURO }_{t-2}-0.0189 \text { DEURO }_{t-3} \\
\text { DEURO }= & 1.23+0.745 \text { DTUFE } \\
& +0.026 \text { DEURO } O_{t-1}-0.117 \text { DEURO } O_{t-2}-0.086 \text { DEURO } E_{t-3}
\end{aligned}
$$

Euro kuru ile tahmin edilen VAR modeli sonucunda elde edilen Etki-Tepki analizi sonuçları Șekil 5'te verilmiștir. Illk grafikte euro kurunda meydana gelen 1 standart sapmalık șokun enflasyona etkisinin negatif olduğu ve bu etkinin dolar kurunda olduğu gibi ikinci dönemde minimum seviyeye indiği, meydana gelen șokun negatif etkisinin üçüncü dönemde etkinin bașlangıç seviyesine döndüğü görülmektedir.

Response to Cholesky One S.D. Innovations \pm 2 S.E.

TÜFE Değişkeninin EURO değişkenine cevabı

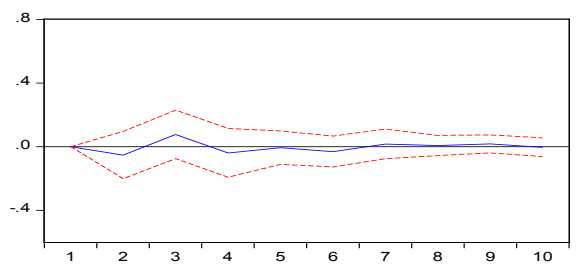

EURO Değişkeninin TÜFE değişkenine cevabı

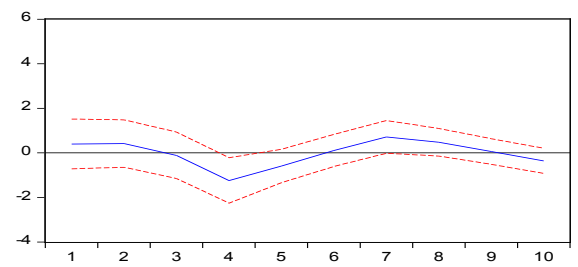

Șekil 5: 2003-2007:12 Dönemi İçin Euro Kuru Ełki - Tepki Analizi Sonuçları

2003-2019:04 dönemi için sepet kur ile elde edilen VAR modeli dört gecikme ile kurulmuș ve elde edilen katsayılar așağıda verilmiștir. Dolar ve Euro kurları ile benzer biçimde sepet kurdaki artıșın enflasyona etkisinin önce negatif ikinci dönemde pozitif olduğu ve yakın dönem etkisinin yüksek olduğunu göstermektedir.

$$
\begin{aligned}
& D T U F E=0.85+0.317 D T U F E_{t-1}-0.078 D T U F E_{t-2}-0.47 D T U F E_{t-3} \\
& -0.018 \text { DSEPET }_{t-1}+0.02 \text { DSEPET }_{t-2}-0.0159 D_{S E P E T} \\
& D S E P E T=1.06+0.524 D T U F E_{t-1}-0.536 D T U F E_{t-2}-1.78 D T U F E_{t-3} \\
& +0.0589 D_{S E P E T_{t-1}}-0.143 \mathrm{DSEPET}_{t-2}-0.05146 \mathrm{DSEPET}_{t-3}
\end{aligned}
$$

VAR modeli sonucunda elde edilen Ełki-Tepki analizi sonuçları Șekil 6'da verilmiștir. Illk grafikte görülen dolar kurunda meydana gelen 1 standart sapmalık șokun enflasyona önce negatif etki yaptığı, bu etkinin ikinci dönemde minimum seviyeye indiği görülmektedir. Meydana gelen șokun negatif etkisi üçüncü dönemde yok olmaktadır. 
Response to Cholesky One S.D. Innovations \pm 2 S.E.

TÜFE Değişkeninin SEPET değişkenine cevabı

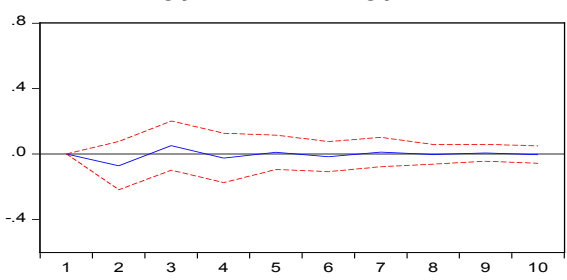

SEPET Değişkeninin TÜFE değişkenine cevabı

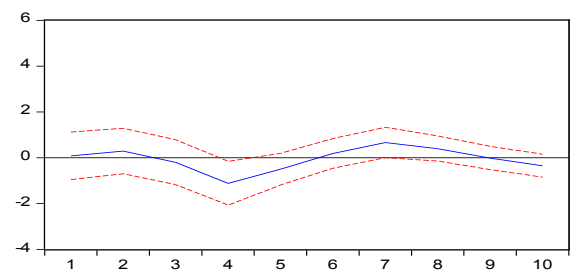

Șekil 6: 2003-2007:12 Dönemi İçin Sepet Kur Ełki - Tepki Analizi Sonuçları

2003-2007: 12 dönemi için elde edilen VAR modeli iki gecikme ile kurulmuș ve elde edilen bulgular așağıda verilmiștir. Modeler incelendiğinde ilk modelin dolar kurundaki artıșın Enflasyona etkisinin ilk dönemde negatif ikinci dönemde pozitif olduğu görülmüștür. Etkinin ișaretinin farklı olması bu dönemin yapısından kaynaklanmaktadır. 2008-2012 yılları arasında tablo 1 'de de görüleceği üzere ortalama kur seviyesinde artıș olduğu, ancak enflasyonun ortalama değerlerinin en düșük olduğu dönemdir. Bu dönemlerde dolar kurunda artıșın ilk etapta negatif ikinci dönemde pozitif etki yaratması beklentilerin etkinliğine ișaret etmektedir.

$$
\begin{aligned}
& \text { DTUFE }=0.604+0.25 \text { DTUFE }_{t-1}-0.194 \text { DTUFE }_{t-2}-0.0044 D U S D_{t-1}+0.01 \text { DUSD }_{t-2} \\
& D U S D=0.878+0.511 \text { DTUFE }_{t-1}-0.581 D T U F E_{t-2}+0.157 D U S D_{t-1}-0.1819 D U S D_{t-2}
\end{aligned}
$$

VAR modeli sonucunda elde edilen Etki-Tepki analizi sonuçları Șekil 7'de verilmiștir. Illk grafikte görülen dolar kurunda meydana gelen 1 standart sapmalık șokun enflasyona önce negatif etki yaptığı, bu etkinin ikinci dönemde minimum seviyeye indiği ve söndüğü görülmektedir.

Response to Cholesky One S.D. Innovations \pm 2 S.E.

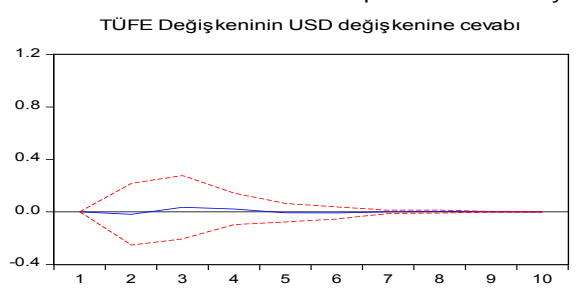

USD Değişkeninin TÜFE değişkenine cevab

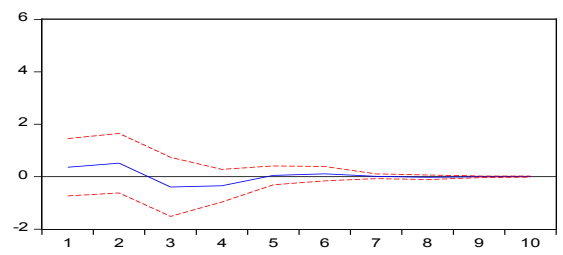

Șekil 7: 2008-2012:12 Dönemi İçin Dolar Kuru Ełki - Tepki Analizi Sonuçları

Euro ile Enflasyon arasındaki ilișkinin 2008-2012:12 dönemi için incelenmiș olduğu VAR modeli tek gecikme ile kurulmuș ve elde edilen 
katsayılar așağıda verilmiștir. Modeller incelendiğinde ilk modelin euro kurundaki artıșın enflasyona etkisinin pozitif olduğu görülmektedir.

$$
\begin{aligned}
& \text { DTUFE }=0.488+0.1997 \text { DTUFE }_{t-1}+0.0468 \text { DEURO }_{t-1} \\
& \text { DEURO }=0.658-0.2298 \text { DTUFE }_{t-1}+0.145 \text { DEURO } \\
& t-1
\end{aligned}
$$

Euro kuru ile tahmin edilen VAR modeli sonucunda elde edilen Etki-Tepki analizi sonuçları Șekil 8'de verilmiștir. İlk grafikte euro kurunda meydana gelen 1 standart sapmalık șokun enflasyona etkisinin pozitif olduğu ve bu etkinin ikinci dönemde maksimum seviyeye ulaștığı, etkinin kaybolmasının ise dördüncü döneme kadar sürdüğü görülmektedir.

Response to Cholesky One S.D. Innovations \pm 2 S.E.

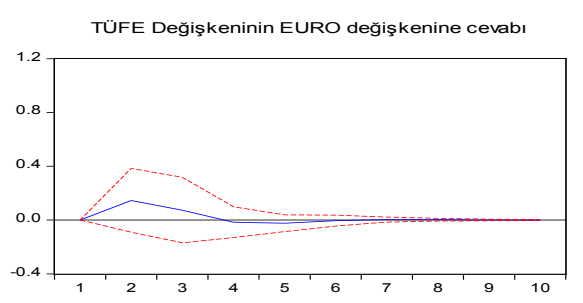

EURO Değişkeninin TÜFE değişkenine cevabı

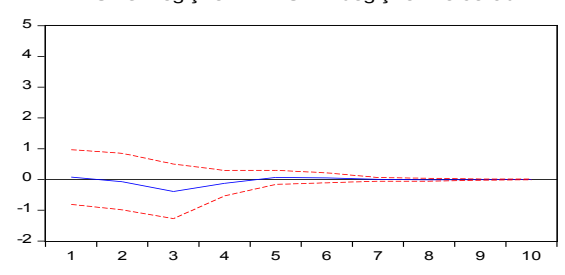

Șekil 8: 2008-2012:12 Dönemi İçin Euro Kuru Etki - Tepki Analizi Sonuçları

2008-2012:12 dönemi için sepet kur ile elde edilen VAR modeli tek gecikme ile kurulmuș ve elde edilen katsayılar așağıda verilmiștir. Modeller incelendiğinde ilk modelin sepet kurdaki artıșın enflasyona etkisinin euro kurunda olduğu gibi benzer șekilde pozitif olduğu görülmektedir.

$$
\begin{aligned}
& \text { DTUFE }=0.496+0.2015 \text { DTUFE }_{t-1}+0.0247 \text { DSEPET }_{t-1} \\
& D S E P E T=0.521+0.03 \text { DTUFE }_{t-1}+0.195 D S E P E T_{t-1}
\end{aligned}
$$

Sepet kur ile tahmin edilen VAR modeli sonucunda elde edilen Etki-Tepki analizi sonuçları Șekil 9'da verilmiștir. Illk grafikte Sepet kurda meydana gelen 1 standart sapmalık șokun enflasyona etkisinin pozitif olduğu ve bu etkinin dolar ve Euro kurunda olduğu gibi ikinci dönemde maksimum seviyeye çıktığı, meydana gelen șokun pozitif etkisinin dördüncü dönemde yok olduğu görülmektedir. 
Response to Cholesky One S.D. Innovations \pm 2 S.E.

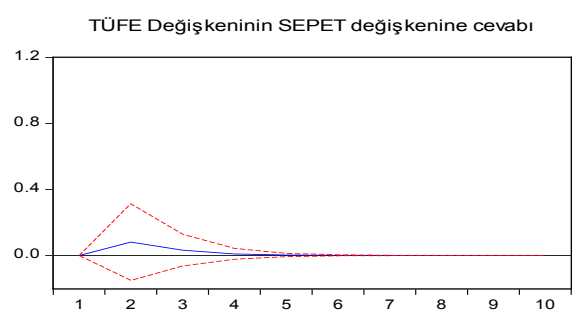

SEPET Değişkeninin TÜFE değişkenine cevabı

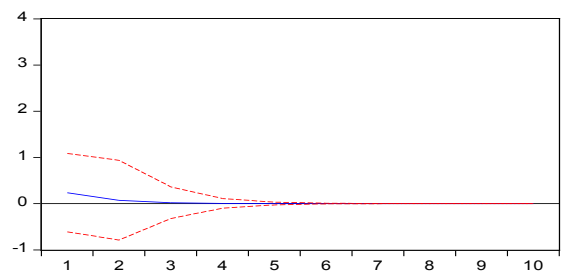

\section{Șekil 9: 2008-2012:12 Dönemi İçin Sepet Kur Ełki - Tepki Analizi Sonuçları}

2013-2017:12 dönemi için elde edilen VAR modeli dört gecikme ile kurulmuș ve elde edilen katsayılar așağıda verilmiștir. Modeller incelendiğinde ilk modelin dolar kurundaki artıșın enflasyona etkisinin ilk iki dönem pozitif olduğu görülmektedir. İncelenen dönem, döviz kurları ve enflasyonun artıș yönünde hareket ettiği dönemdir.

$$
\begin{aligned}
& \text { DTUFE }=0.68+0.208 \text { DTUFE }_{t-1}-0.315 \text { DTUFE }_{t-2}+0.374 \text { DTUFE }_{t-3}-0.416 D T U F E_{t-4} \\
& +0.051 \text { DUSD }_{t-1}+0.0516 \text { DUSD }_{t-2}-0.0292 \text { DUSD }_{t-3}+0.033 \text { DUSD }_{t-4} \\
& D U S D=3.83-0.584 \text { DTUFE }_{t-1}-1.0473 \text { DTUFE }_{t-2}-1.047 \text { DTUFE }_{t-3}-0.8227 D_{\text {TUFE }}{ }_{t-4} \\
& -0.0043 \text { DUSD }_{t-1}+0.0054 \text { DUSD }_{t-2}-0.183 \text { DUSD }_{t-3}+0.145 \text { DUSD }_{t-4}
\end{aligned}
$$

VAR modeli sonucunda elde edilen Etki-Tepki analizi sonuçları Șekil 10'da verilmiștir. Illk grafikte görülen dolar kurunda meydana gelen 1 standart sapmalık șokun enflasyona pozitif etki yaptığı ve bu etkinin üçüncü dönemde maksimum seviyeye çıktığı görülmektedir. Meydana gelen șokun pozitif etkisi dördüncü dönemde yok olmaktadır.

Response to Cholesky One S.D. Innovations \pm 2 S.E.

TÜFE Değişkeninin USD değişkenine cevabı

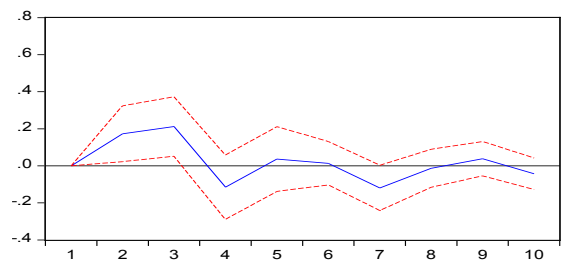

USD Değişkeninin TÜFE değişkenine cevabı

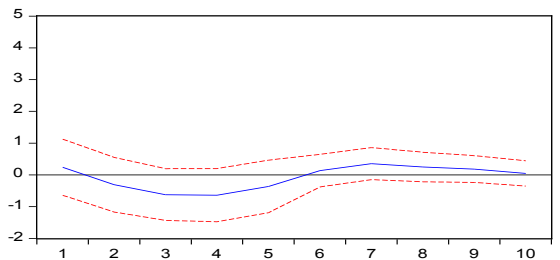

\section{Șekil 10: 2013:01-2017:12 Dönemi İçin Dolar Kuru Ełki - Tepki Analizi Sonuçları}

2013-2017:12 dönemi için elde edilen VAR modeli dört gecikme ile kurulmuș ve elde edilen katsayılar așağıda verilmiștir. Modeller incelendiğinde, ilk modelin dolar kurundaki artıșın enflasyona etkisinin ilk iki 
dönem pozitif olduğu görülmektedir. Incelenen dönem, döviz kurları ve enflasyonun artıș yönünde hareket ettiği dönemdir.

$$
\begin{aligned}
& \underset{\text { Centre Text }}{\operatorname{naminf}}=0.759+0.232 D T U F E_{t-1}-0.333 \text { DTUFE } E_{t-2}+0.34 D T U F E_{t-3}-0.478 D T U F E_{t-4} \\
& +0.0492 \text { DEURO }_{t-1}+0.0322 \text { DEURO }_{t-2}-0.0141 \text { DEURO }_{t-3}+0.0414 \text { DEURO }_{t-4} \\
& D E U R O=2.538-0.578 D T U F E_{t-1}-0.752 D T U F E_{t-2}-0.1898 D T U F E_{t-3}-0.396 D T U F E_{t-4} \\
& -0.054 \text { DEURO }{ }_{t-1}+0.0472 \text { DEURO }_{t-2}-0.1946 \text { DEURO }_{t-3}+0.177 \text { DEURO }_{t-4}
\end{aligned}
$$

VAR modeli sonucunda elde edilen Etki-Tepki analizi sonuçları Șekil 11 'de verilmiștir. İlk grafikte görülen euro kurunda meydana gelen 1 standart sapmalık șokun enflasyona pozitif etki yaptığı ve bu etkinin ikinci dönemde maksimum seviyeye çıkığı görülmektedir. Meydana gelen șokun pozitif etkisi dördüncü dönemde yok olmaktadır.

Response to Cholesky One S.D. Innovations \pm 2 S.E.

TÜFE Değişkeninin EURO değişkenine cevabı

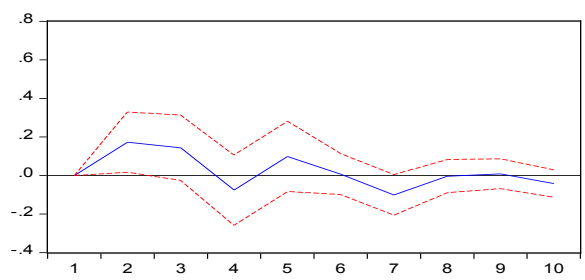

EURO Değişkeninin TÜFE değişkenine cevabı

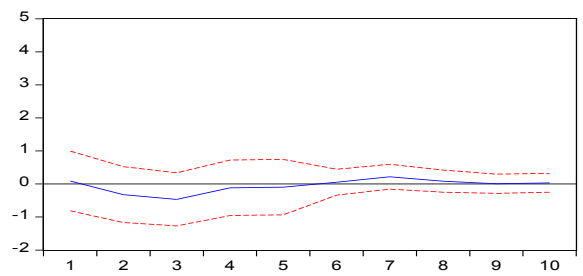

\section{Șekil 11: 2013:01-2017:12 Dönemi İçin Euro Kuru Ełki - Tepki Analizi Sonuçları}

2013-2017:12 dönemi için elde edilen VAR modeli dört gecikme ile kurulmuș ve elde edilen katsayılar așağıda verilmiștir. Modeller incelendiğinde, ilk modelin dolar kurundaki artıșın enflasyona etkisinin ilk iki dönem pozitif olduğu görülmektedir. İncelenen dönem, döviz kurları ve enflasyonun artıș yönünde hareket ettiği dönemdir.

$$
\begin{aligned}
\text { DTUFE }= & 0.71+0.206 \text { DTUFE }_{t-1}-0.33 \text { DTUFE }_{t-2}+0.355 \text { DTUFE }_{t-3}-0.44 D T U F E_{t-4} \\
& +0.0577 \text { DSEPET }_{t-1}+0.0475 \text { DSEPET }_{t-2}-0.0198 D S E P E T_{t-3}+0.045 D S E P E T_{t-4} \\
\text { DSEPET }= & 3.14-0.4835 \text { DTUFE }_{t-1}-0.864 D T U F E_{t-2}-0.565 \text { DTUFE }_{t-3}-0.69 D T U F E_{t-4} \\
& -0.0427 \text { DSEPET }_{t-1}+0.0126 \text { DSEPET }_{t-2}-0.229 \text { DSEPET }_{t-3}+0.1457 \text { DSEPET }_{t-4}
\end{aligned}
$$

VAR modeli sonucunda elde edilen Etki-Tepki analizi sonuçları Șekil 12'de verilmiștir. Illk grafikte görülen sepet kurda meydana gelen 1 standart sapmalık șokun enflasyona pozitif etki yaptığı ve bu etkinin ikinci dönemde maksimum seviyeye çıktığı görülmektedir. Meydana gelen șokun pozitif etkisi dördüncü dönemde yok olmaktadır. 
Response to Cholesky One S.D. Innovations \pm 2 S.E.

TÜFE Değişkeninin SEPET değişkenine cevabı

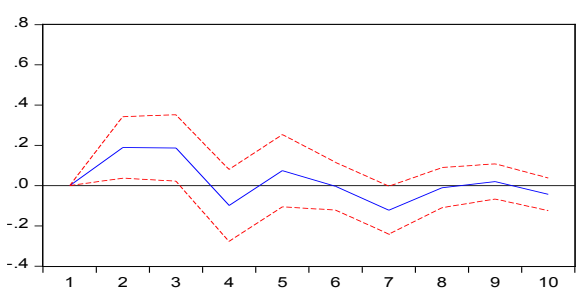

SEPETDeğişkeninin TÜFE değişkenine cevabı

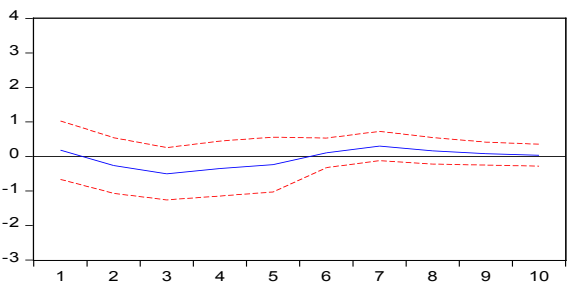

\section{Șekil 12: 2013:01-2017:12 Dönemi İçin Sepet Kur Ełki - Tepki Analizi} Sonuçları

Tüm bu bilgiler ıșığında döviz kurunun tüketici enflasyonuna etkisi gerek mal grupları gerekse toplulaștırılmıș veriler ıșığında incelenmiștir. Elde edilen bulgular yaklașık üç ila dört dönem boyunca döviz etkisinin fiyatlara yansıdığını, etkinin farklı dönemlerde farklı mal gruplarına ve farklı büyüklükte olduğunu göstermektedir.

\section{Sonuç ve Değerlendirme}

Çalıșmada Tüketici Fiyat Endeksi ile Döviz kuru arasındaki ilișki dinamiği incelenmiștir. Analiz 394 ürün fiyat bilgisinden hareketle 12 ürün grubu için Dolar kuru, Euro kuru ve Sepet kur ilișkisi üzerinden korelasyon hesaplanarak yapılmıștır. 2003-2008, 2008-2013, 20132017, 2018-2019 dönemleri ve tüm dönemin söz konusu olduğu 20032019 dönemleri için analiz yapılmıștır.

Enflasyonun düșüș eğiliminde olduğu 2003-2007 döneminde ilișkinin yönü ve büyüklüğü diğer dönemlerden farklıdır. Bu dönemde ilișki ürün grupları bazında incelendiğinde negatif ya da zayıf ve pozitif yöndedir. Daha sonraki dönemlerde enflasyon arttıkça, döviz kurundaki artıșa paralel olarak pozitif ilișkinin gücü de artıș göstermiștir. Bu analizden elde edilen bir diğer bulgu ise, döviz kurundaki ve enflasyondaki artıșın giderek arttığı dönemde cari ay etkilerinin görece daha yüksek olduğu görülmüștür.

İkinci așamada 2003-2008, 2008-2013, 2013-2017 dönemleri ve tüm dönemin söz konusu olduğu 2003-2019 dönemleri için Dolar kuru, Euro kuru ve Sepet kur ile TÜFE arasında VAR analizi ile kısa dönem dinamikleri incelenmiștir. 
Analiz döneminin tümü dikkate alındığında döviz kurunda meydana gelen bir șok, enflasyona pozitif etki etmekte, etkinin dengelenmesi 4 dönem sürmektedir. 2003-2007 döneminde kurda meydana gelen pozitif yönlü bir șokun etkisi negatif olmuș ve etki iki dönem sonunda yok olmuștur. 2008-2012 döneminde dolar, euro ve sepet kur etkisi farklılașmıștır. Euro ve sepet kurdaki pozitif bir șokun etkisi enflasyona pozitif etki yapmıș ve etkinin yok olması yaklașık 4 dönem sürmüștür. Dolar kurunda ise etki negatif ve çok düșük düzeydedir. 2013-2017 döneminde benzer biçimde döviz kurunda meydana gelen etkinin yönü pozitif ve kalıcılığı üç dönem olmuștur.

Elde edilen bulgular ıșığında döviz kuru ile tüketici fiyat endeksi arasındaki ilișki döviz kurunun ve enflasyonun yüksek olduğu dönemde birbirini etkileyen ve pozitif yönelimlidir. Incelenen dönemler uygulanan ekonomi politikaları ve ekonomik ve siyasi koșullar bakımından da farklılașmaktadır. Bu durum ayrıntılı olarak verilmiș olan sonuçların politika analizinde kullanılmasını mümkün kılmaktadır. Koșulların değișmesi halinde hangi sektörlerin ve ürünlerin fiyatlarının döviz kurundan daha fazla etkilendiği ve hane halkı tüketimindeki payı analiz sonuçlarında elde edilmiș ve tablolar ile sunulmuștur. 


\section{Kaynakça}

Berument $H_{\text {. }}$ (2002). "Döviz Kuru Hareketleri ve Enflasyon Dinamiği: Türkiye Örneği", Bilkent Üniversitesi Yayınları.

Bonsu, C.O ve Muzindutsi, P. (2017). Macroeconomic Determinants of Household Consumption Expenditure in Ghana: A Multivariate Cointegration Approach, International Journal of Economics and Financial Issues, 7(4), 737-745.

Chung, E., M. Kohler and C. Lewis (2011) The Exchange Rate and Consumer Prices, Reserve Bank of Australia Bulletin, September, 9-16.

Dickey, D.A., ve W.A. Fuller (1979), "Distribution of the estimators for autoregressive time series with a unit root", Journal of the American Statistical Association, 74, 427-431.

Dickey, D.A. ve W.A. Fuller (1981), "Distribution of the estimators for autoregressive time series with a unit root", Econometrica, 49, 1057-72.

Gül E. ve Ekinci A. (2006). Türkiye'de Enflasyon ve Döviz Kuru Arasındaki Nedensellik ilișkisi: 1984 -2003, Sosyal Bilimler Dergisi, 91-106.

Karahan, O. (2017). Exchange Rate Pass-Through in Turkey Before and After the Adoption of Inflation Targeting Regime, Financial Asset and Investing, 8(2), 37-48.

Phillips, P. ve Perron, P (1988). Testing for unit root in time series regression, Biometrika, 74, 335-346. 


\section{Tablo 2: 2003-2019 Döneminde döviz kurları ile fiyat artıșı arasındaki korelasyon}

\begin{tabular}{|c|c|c|c|c|c|c|c|}
\hline \multirow[t]{3}{*}{ SEPET } & & \multicolumn{2}{|c|}{ USD } & \multicolumn{2}{|c|}{ EURO } & \multicolumn{2}{|c|}{ SEPET } \\
\hline & \multicolumn{2}{|c|}{ DOLAR ILE KORELASYON } & \multicolumn{2}{|c|}{ EURO ILE KORELASYON } & \multicolumn{2}{|c|}{$\begin{array}{l}\text { SEPET KUR ILE } \\
\text { KORELASYON }\end{array}$} & \\
\hline & $\% 51-\% 89$ & \%90 ÜZERi & $\% 51-\% 89$ & \%90 ÜZERi & $\% 51-\% 89$ & \%90 ÜZERi & \\
\hline TOPLAM & & 46,76 & 49,32 & 46,19 & 54,65 & 46,01 & 54,78 \\
\hline Gıda ve Alkolsüz İçecekler & 23,29 & 12,49 & 10,45 & 11,81 & 11,19 & 11,87 & 11,07 \\
\hline Alkollü İçecekler ve Tütün & 4,23 & 3,87 & 0,36 & 3,87 & 0,36 & 3,87 & 0,36 \\
\hline Giyim ve Ayakkabı & 7,24 & 4,05 & 2,63 & 4,05 & 2,69 & 4,05 & 2,69 \\
\hline Konut & 15,16 & 10,57 & 4,59 & 10,14 & 5,02 & 10,14 & 5,02 \\
\hline Ev Eșyası & 8,33 & 2,10 & 5,90 & 1,99 & 6,00 & 1,83 & 6,16 \\
\hline Sağlık & 2,58 & 0,85 & 1,18 & 0,85 & 1,18 & 0,85 & 1,18 \\
\hline Ulaștırma & 16,78 & 6,80 & 9,98 & 6,03 & 10,75 & 6,03 & 10,75 \\
\hline Haberleșme & 3,69 & 2,32 & 0,83 & 2,32 & 0,83 & 2,32 & 0,83 \\
\hline Eğlence ve Kültür & 3,29 & 1,37 & 1,46 & 1,84 & 0,98 & 1,84 & 0,98 \\
\hline Eğitim & 2,40 & 0,93 & 1,47 & 0,93 & 1,47 & 0,93 & 1,47 \\
\hline Lokanta ve Oteller & 7,86 & 0,37 & 6,87 & 0,37 & 6,87 & 0,37 & 6,87 \\
\hline Çeșitli Mal ve Hizmetler & 5,15 & 1,04 & 3,61 & 0,95 & 3,70 & 0,95 & 3,70 \\
\hline
\end{tabular}

\section{Tablo 3: 2003-2019 Döneminde döviz kurları ile bir sonraki dönem $(t+1)$ fiyat artıșı arasındaki korelasyon}

\begin{tabular}{|c|c|c|c|c|c|c|c|}
\hline \multirow[t]{3}{*}{ SEPET $(t+1)$} & & \multicolumn{2}{|c|}{ USD } & \multicolumn{2}{|c|}{ EURO } & \multicolumn{2}{|c|}{ SEPET } \\
\hline & \multicolumn{2}{|c|}{ DOLAR ILE KORELASYON } & \multicolumn{2}{|c|}{ EURO ILE KORELASYON } & \multicolumn{2}{|c|}{$\begin{array}{l}\text { SEPET KUR ILE } \\
\text { KORELASYON }\end{array}$} & \\
\hline & $\% 51-\% 89$ & \%90 ÜZERi & $\% 51-\% 89$ & \%90 ÜZERi & $\% 51-\% 89$ & \%90 ÜZERi & \\
\hline TOPLAM & & 47,31 & 53,42 & 44,99 & 55,85 & 45,11 & 55,74 \\
\hline Gıda ve Alkolsüz İçecekler & 23,29 & 12,31 & 10,63 & 11,49 & 11,51 & 11,55 & 11,45 \\
\hline Alkollü İçecekler ve Tütün & 4,23 & 3,87 & 0,36 & 3,87 & 0,36 & 3,87 & 0,36 \\
\hline Giyim ve Ayakkabı & 7,24 & 4,03 & 2,65 & 4,03 & 2,71 & 4,03 & 2,71 \\
\hline Konut & 15,16 & 10,57 & 4,59 & 10,14 & 5,02 & 10,14 & 5,02 \\
\hline Ev Eșyası & 8,33 & 1,98 & 6,01 & 1,16 & 6,83 & 1,83 & 6,16 \\
\hline Sağlık & 2,58 & 0,85 & 1,18 & 0,85 & 1,18 & 0,85 & 1,18 \\
\hline Ulaștırma & 16,78 & 6,79 & 9,99 & 6,01 & 10,77 & 6,03 & 10,75 \\
\hline Haberleșme & 3,69 & 2,32 & 0,83 & 2,32 & 0,83 & 2,32 & 0,83 \\
\hline Eğlence ve Kültür & 3,29 & 1,30 & 1,52 & 1,83 & 1,00 & 1,28 & 1,54 \\
\hline Eğitim & 2,40 & 0,93 & 1,47 & 0,93 & 1,47 & 0,93 & 1,47 \\
\hline Lokanta ve Oteller & 7,86 & 0,37 & 6,87 & 0,37 & 6,87 & 0,37 & 6,87 \\
\hline Çeșitli Mal ve Hizmetler & 5,15 & 1,04 & 3,61 & 0,95 & 3,70 & 0,95 & 3,70 \\
\hline
\end{tabular}


Tablo 4: 2003-2019 Döneminde döviz kurları ile üç dönem sonraki (t+3) fiyat artıșı arasındaki korelasyon

\begin{tabular}{|c|c|c|c|c|c|c|c|}
\hline \multirow[t]{3}{*}{ SEPET $(t+3)$} & & \multicolumn{2}{|c|}{ USD } & \multicolumn{2}{|c|}{ EURO } & \multicolumn{2}{|c|}{ SEPET } \\
\hline & \multicolumn{2}{|c|}{ DOLAR ILE KORELASYON } & \multicolumn{2}{|c|}{ EURO ILE KORELASYON } & \multicolumn{2}{|c|}{ SEPET KUR ILE KORELASYON } & \\
\hline & $\% 51-\% 89$ & \%90 ÜZERI & $\% 51-\% 89$ & \%90 ÜZERI & $\% 51-\% 89$ & \%90 ÜZERI & \\
\hline TOPLAM & & 52,06 & 48,79 & 52,15 & 48,70 & 52,15 & 48,70 \\
\hline Gıda ve Alkolsüz İçecekler & 23,29 & 15,60 & 7,40 & 15,60 & 7,40 & 15,60 & 7,40 \\
\hline Alkollü İçecekler ve Tütün & 4,23 & 3,87 & 0,36 & 3,87 & 0,36 & 3,87 & 0,36 \\
\hline Giyim ve Ayakkabı & 7,24 & 4,08 & 2,66 & 4,08 & 2,66 & 4,08 & 2,66 \\
\hline Konut & 15,16 & 10,57 & 4,59 & 10,57 & 4,59 & 10,57 & 4,59 \\
\hline Ev Eșyası & 8,33 & 2,20 & 5,79 & 2,20 & 5,79 & 2,20 & 5,79 \\
\hline Sağlık & 2,58 & 0,85 & 1,18 & 0,85 & 1,18 & 0,85 & 1,18 \\
\hline Ulaștırma & 16,78 & 7,99 & 8,79 & 7,99 & 8,79 & 7,99 & 8,79 \\
\hline Haberleșme & 3,69 & 2,32 & 0,83 & 2,32 & 0,83 & 2,32 & 0,83 \\
\hline Eğlence ve Kültür & 3,29 & 1,28 & 1,54 & 1,28 & 1,54 & 1,28 & 1,54 \\
\hline Eğitim & 2,40 & 0,93 & 1,47 & 0,93 & 1,47 & 0,93 & 1,47 \\
\hline Lokanta ve Oteller & 7,86 & 0,37 & 6,87 & 0,37 & 6,87 & 0,37 & 6,87 \\
\hline Çeșitli Mal ve Hizmetler & 5,15 & 1,04 & 3,61 & 1,04 & 3,61 & 1,04 & 3,61 \\
\hline
\end{tabular}

Tablo 5: 2003-2007 Döneminde döviz kurları ile fiyat artıșı arasındaki korelasyon

\begin{tabular}{|l|c|c|c|c|c|c|c|c|}
\hline & & \multicolumn{3}{|c}{ USD } & \multicolumn{2}{c|}{ EURO } & \multicolumn{2}{c|}{ SEPET } \\
\hline & DOLET & NEGATiF & \%50'DEN AZ & NEGATiF & \%50'DEN AZ & NEGATiF & \%50'DEN AZ & \\
\hline & & 87,07 & 5,29 & 15,21 & 80,26 & 78,65 & 17,26 \\
\hline TOPLAM & & 21,56 & 1,11 & 1,74 & 20,59 & 18,80 & 3,88 \\
\hline Gida ve Alkolsüz İçecekler & $\mathbf{2 3 , 2 9}$ & $\mathbf{4 , 2 3}$ & 0,36 & 0,00 & 0,00 & 0,36 & 0,36 & 0,00 \\
\hline Alkollü İçecekler ve Tütün & $\mathbf{4 , 2 4}$ & 5,98 & 0,60 & 0,39 & 6,19 & 5,72 & 0,86 \\
\hline Giyim ve Ayakkabı & $\mathbf{1 5 , 1 6}$ & 15,12 & 0,00 & 1,92 & 13,20 & 14,72 & 0,40 \\
\hline Konut & $\mathbf{8 , 3 3}$ & 6,96 & 0,95 & 1,99 & 5,92 & 6,99 & 0,92 \\
\hline Ev Eșyası & $\mathbf{2 , 5 8}$ & 2,16 & 0,42 & 0,29 & 2,23 & 0,57 & 2,01 \\
\hline Sağlık & $\mathbf{1 6 , 7 8}$ & 16,52 & 0,04 & 0,12 & 16,44 & 13,74 & 2,82 \\
\hline Ulaștırma & $\mathbf{3 , 6 9}$ & 2,91 & 0,79 & 2,86 & 0,83 & 2,37 & 1,33 \\
\hline Haberleșme & $\mathbf{3 , 2 9}$ & 1,85 & 0,57 & 0,75 & 1,83 & 1,52 & 1,11 \\
\hline Eğlence ve Kültür & $\mathbf{2 , 4 0}$ & 2,40 & 0,00 & 0,00 & 2,40 & 2,40 & 0,00 \\
\hline Eğitim & $\mathbf{7 , 8 6}$ & 7,17 & 0,00 & 0,00 & 7,17 & 7,17 & 0,00 \\
\hline Lokanta ve Oteller & $\mathbf{5 , 1 5}$ & 4,10 & 0,61 & 1,03 & 2,49 & 3,27 & 1,45 \\
\hline Çeșitli Mal ve Hizmetler & & & & & & & EURO iLE KORELASYON \\
\hline
\end{tabular}


Tablo 6: 2003-2007 Döneminde döviz kurları ile bir sonraki dönem (t+1) fiyat artıșı arasındaki korelasyon

\begin{tabular}{|l|c|c|c|c|c|c|c|c|}
\hline & & \multicolumn{3}{|c|}{ USD } & \multicolumn{3}{c|}{ EURO } & \multicolumn{3}{c|}{ SEPET } \\
\hline & DELART (t+1) & NEGATiF & \%50'DEN AZ & NEGATiF & \%50'DEN AZ & NEGATiF & \%50'DEN AZ & \\
\hline & & 90,44 & 5,76 & 11,98 & 83,84 & 79,09 & 17,89 \\
\hline TOPLAM & $\mathbf{2 3 , 2 9}$ & 21,80 & 0,87 & 1,48 & 20,09 & 19,12 & 3,55 \\
\hline Gida ve Alkolsüz İçecekler & $\mathbf{4 , 2 3}$ & 0,36 & 0,00 & 0,00 & 0,36 & 0,36 & 0,00 \\
\hline Alkollü İçecekler ve Tütün & $\mathbf{7 , 2 4}$ & 5,96 & 0,62 & 0,39 & 6,19 & 5,36 & 1,22 \\
\hline Giyim ve Ayakkabı & $\mathbf{1 5 , 1 6}$ & 15,12 & 0,00 & 1,92 & 13,20 & 14,72 & 0,40 \\
\hline Konut & $\mathbf{8 , 3 3}$ & 6,93 & 0,88 & 1,97 & 5,83 & 6,27 & 1,54 \\
\hline Ev Eșyası & $\mathbf{2 , 5 8}$ & 2,11 & 0,44 & 0,31 & 2,22 & 1,96 & 0,62 \\
\hline Sağlık & $\mathbf{1 6 , 7 8}$ & 16,52 & 0,04 & 0,12 & 16,44 & 13,72 & 2,84 \\
\hline Ulaștırma & $\mathbf{3 , 6 9}$ & 2,91 & 0,79 & 0,00 & 3,69 & 2,37 & 1,33 \\
\hline Haberleșme & $\mathbf{3 , 2 9}$ & 1,80 & 0,08 & 0,75 & 1,88 & 1,52 & 1,11 \\
\hline Eğlence ve Kültür & $\mathbf{2 , 4 0}$ & 2,40 & 0,00 & 0,00 & 2,40 & 2,40 & 0,00 \\
\hline Eğitim & $\mathbf{7 , 8 6}$ & $\mathbf{7 , 1 7}$ & 0,00 & 0,00 & 7,17 & 7,17 & 0,00 \\
\hline Lokanta ve Oteller & $\mathbf{5 , 1 5}$ & 4,10 & 0,61 & 0,93 & 3,78 & 3,21 & 1,51 \\
\hline Çeșitli Mal ve Hizmetler & & & & & & & \\
\hline
\end{tabular}

Tablo 7: 2003-2007 Döneminde döviz kurları ile üç dönem sonraki (t+3) fiyat artıșı arasındaki korelasyon

\begin{tabular}{|c|c|c|c|c|c|c|c|}
\hline \multirow[t]{3}{*}{ SEPET $(t+3)$} & & \multicolumn{2}{|c|}{ USD } & \multicolumn{2}{|c|}{ EURO } & \multicolumn{2}{|l|}{ SEPET } \\
\hline & \multicolumn{2}{|c|}{ DOLAR ILE KORELASYON } & \multicolumn{2}{|c|}{ EURO ILE KORELASYON } & \multicolumn{2}{|c|}{ SEPET KUR ILE KORELASYON } & \\
\hline & NEGATiF & $\% 50^{\prime}$ DEN AZ & NEGATiF & $\% 50^{\prime}$ DEN AZ & NEGATiF & $\% 50^{\prime}$ DEN AZ & \\
\hline TOPLAM & & 90,06 & 6,13 & 90,58 & 5,62 & 90,58 & 5,62 \\
\hline Gıda ve Alkolsüz icçecekler & 23,29 & 22,27 & 0,47 & 22,27 & 0,47 & 22,27 & 0,47 \\
\hline Alkollü İçecekler ve Tütün & 4,23 & 0,36 & 0,00 & 0,36 & 0,00 & 0,36 & 0,00 \\
\hline Giyim ve Ayakkabı & 7,24 & 5,75 & 0,83 & 5,75 & 0,83 & 5,75 & 0,83 \\
\hline Konut & 15,16 & 15,12 & 0,00 & 15,12 & 0,00 & 15,12 & 0,00 \\
\hline Ev Eșyası & 8,33 & 6,64 & 1,28 & 6,64 & 1,28 & 6,64 & 1,28 \\
\hline Sağlık & 2,58 & 2,11 & 0,19 & 2,11 & 0,19 & 2,11 & 0,19 \\
\hline Ulaștırma & 16,78 & 16,52 & 0,04 & 16,52 & 0,04 & 16,52 & 0,04 \\
\hline Haberleșme & 3,69 & 2,91 & 0,79 & 2,91 & 0,79 & 2,91 & 0,79 \\
\hline Eğlence ve Kültür & 3,29 & 1,83 & 0,04 & 1,83 & 0,04 & 1,83 & 0,04 \\
\hline Eğitim & 2,40 & 2,40 & 0,00 & 2,40 & 0,00 & 2,40 & 0,00 \\
\hline Lokanta ve Oteller & 7,86 & 7,24 & 0,00 & 7,24 & 0,00 & 7,24 & 0,00 \\
\hline Çeșitli Mal ve Hizmetler & 5,15 & 3,72 & 0,99 & 3,72 & 0,99 & 3,72 & 0,99 \\
\hline
\end{tabular}


Tablo 8: 2008-2012 Döneminde döviz kurları ile fiyat artıșı arasındaki korelasyon

\begin{tabular}{|c|c|c|c|c|c|c|c|}
\hline \multirow[t]{3}{*}{ SEPET } & & \multicolumn{2}{|c|}{ USD } & \multicolumn{2}{|c|}{ EURO } & \multicolumn{2}{|c|}{ SEPET } \\
\hline & \multicolumn{2}{|c|}{ DOLAR ILE KORELASYON } & \multicolumn{2}{|c|}{ EURO ILE KORELASYON } & \multicolumn{2}{|c|}{ SEPET KUR ILE KORELASYON } & \\
\hline & $\% 50^{\prime}$ DEN AZ & $\% 51-\% 89$ & $\% 50^{\prime}$ DEN AZ & $\% 51-\% 89$ & $\% 50^{\prime}$ DEN AZ & $\% 51-\% 89$ & \\
\hline TOPLAM & & 12,76 & 78,55 & 18,20 & 77,02 & 15,39 & 79,84 \\
\hline Gıda ve Alkolsüz İçecekler & 23,29 & 5,12 & 16,86 & 6,55 & 15,47 & 5,16 & 16,80 \\
\hline Alkollü İçecekler ve Tütün & 4,23 & 0,00 & 0,36 & 0,00 & 0,36 & 0,00 & 0,36 \\
\hline Giyim ve Ayakkabı & 7,24 & 1,37 & 5,30 & 2,81 & 3,87 & 1,80 & 4,88 \\
\hline Konut & 15,16 & 0,40 & 14,75 & 2,21 & 12,95 & 2,21 & 12,95 \\
\hline Ev Essyası & 8,33 & 1,01 & 6,19 & 1,46 & 6,13 & 1,01 & 6,58 \\
\hline Sağlık & 2,58 & 0,63 & 1,80 & 0,66 & 1,69 & 0,67 & 1,77 \\
\hline Ulaștırma & 16,78 & 0,11 & 16,68 & 0,01 & 16,78 & 0,00 & 16,76 \\
\hline Haberleșme & 3,69 & 2,13 & 1,02 & 2,13 & 1,02 & 2,13 & 1,02 \\
\hline Eğlence ve Kültür & 3,29 & 0,11 & 2,15 & 0,86 & 1,41 & 0,85 & 1,42 \\
\hline Eğitim & 2,40 & 0,15 & 2,25 & 0,15 & 2,25 & 0,15 & 2,25 \\
\hline Lokanta ve Oteller & 7,86 & 0,00 & 7,24 & 0,00 & 7,24 & 0,00 & 7,24 \\
\hline Çeșitli Mal ve Hizmetler & 5,15 & 0,75 & 3,95 & 0,63 & 3,92 & 0,80 & 3,92 \\
\hline
\end{tabular}

Tablo 9: 2008-2012 Döneminde döviz kurları ile bir sonraki dönem (t+1) fiyat artıșı arasındaki korelasyon

\begin{tabular}{|c|c|c|c|c|c|c|c|}
\hline \multirow[t]{3}{*}{ SEPET $(t+1)$} & & \multicolumn{2}{|c|}{ USD } & \multicolumn{2}{|c|}{ EURO } & \multicolumn{2}{|c|}{ SEPET } \\
\hline & \multicolumn{2}{|c|}{ DOLAR ILE KORELASYON } & \multicolumn{2}{|c|}{ EURO İLE KORELASYON } & \multicolumn{2}{|c|}{ SEPET KUR ILE KORELASYON } & \\
\hline & $\% 50^{\prime}$ DEN AZ & $\% 51-\% 89$ & $\% 50^{\prime}$ DEN AZ & $\% 51-\% 89$ & $\% 50^{\prime}$ DEN AZ & $\% 51-\% 89$ & \\
\hline TOPLAM & & 13,80 & 81,31 & 18,01 & 77,46 & 15,97 & 79,45 \\
\hline Gıda ve Alkolsüz İçecekler & 23,29 & 5,20 & 16,71 & 5,28 & 16,75 & 5,38 & 16,58 \\
\hline Alkollü İçecekler ve Tütün & 4,23 & 0,00 & 0,36 & 0,00 & 0,36 & 0,00 & 0,36 \\
\hline Giyim ve Ayakkabı & 7,24 & 1,58 & 5,10 & 2,11 & 4,57 & 1,58 & 5,10 \\
\hline Konut & 15,16 & 0,40 & 14,75 & 2,21 & 12,95 & 2,21 & 12,95 \\
\hline Ev Eșyası & 8,33 & 1,01 & 6,34 & 1,89 & 5,70 & 1,01 & 6,58 \\
\hline Sağlık & 2,58 & 1,68 & 0,75 & 1,74 & 0,69 & 1,67 & 0,77 \\
\hline Ulaștırma & 16,78 & 0,00 & 16,78 & 0,08 & 16,71 & 0,00 & 16,78 \\
\hline Haberleșme & 3,69 & 2,13 & 1,02 & 2,13 & 1,02 & 2,13 & 1,02 \\
\hline Eğlence ve Kültür & 3,29 & 0,11 & 2,15 & 0,88 & 1,38 & 0,31 & 1,96 \\
\hline Eğitim & 2,40 & 0,15 & 2,25 & 0,15 & 2,25 & 0,15 & 2,25 \\
\hline Lokanta ve Oteller & 7,86 & 0,00 & 7,24 & 0,00 & 7,24 & 0,00 & 7,24 \\
\hline Çeșitli Mal ve Hizmetler & 5,15 & 0,75 & 3,95 & 0,80 & 3,92 & 0,75 & 3,97 \\
\hline
\end{tabular}


Tablo 10: 2008-2012 Döneminde döviz kurları ile üç dönem sonraki (t+3) fiyat artıșı arasındaki korelasyon

\begin{tabular}{|c|c|c|c|c|c|c|c|}
\hline \multirow[t]{3}{*}{ SEPET $(t+3)$} & & \multicolumn{2}{|c|}{ USD } & \multicolumn{2}{|c|}{ EURO } & \multicolumn{2}{|c|}{ SEPET } \\
\hline & \multicolumn{2}{|c|}{ DOLAR ILE KORELASYON } & \multicolumn{2}{|c|}{ EURO ILE KORELASYON } & \multicolumn{2}{|c|}{ SEPET KUR ILE KORELASYON } & \\
\hline & $\% 50^{\prime}$ DEN AZ & $\% 51-\% 89$ & $\% 50^{\prime}$ DEN AZ & $\% 51-\% 89$ & $\% 50^{\prime}$ DEN AZ & $\% 51-\% 89$ & \\
\hline TOPLAM & & 15,53 & 80,03 & 22,57 & 77,30 & 14,56 & 81,50 \\
\hline Gıda ve Alkolsüz i̇çecekler & 23,29 & 4,83 & 17,10 & 5,29 & 16,81 & 5,20 & 16,87 \\
\hline Alkollü İçecekler ve Tüłün & 4,23 & 0,00 & 0,36 & 3,87 & 0,36 & 0,00 & 0,36 \\
\hline Giyim ve Ayakkabı & 7,24 & 2,05 & 4,63 & 3,26 & 3,42 & 2,25 & 4,49 \\
\hline Konut & 15,16 & 2,21 & 12,95 & 2,21 & 12,95 & 2,21 & 12,95 \\
\hline Ev Eșyası & 8,33 & 0,57 & 7,00 & 1,43 & 6,31 & 0,91 & 6,88 \\
\hline Sağlık & 2,58 & 1,75 & 0,75 & 1,83 & 0,75 & 1,83 & 0,75 \\
\hline Ulaștırma & 16,78 & 0,08 & 16,71 & 0,08 & 16,71 & 0,08 & 16,71 \\
\hline Haberleșme & 3,69 & 2,13 & 1,02 & 2,13 & 1,02 & 0,00 & 3,15 \\
\hline Eğlence ve Kültür & 3,29 & 0,45 & 1,93 & 0,88 & 1,39 & 0,32 & 1,93 \\
\hline Eğitim & 2,40 & 0,15 & 2,25 & 0,15 & 2,25 & 0,15 & 2,25 \\
\hline Lokanta ve Oteller & 7,86 & 0,00 & 7,24 & 0,00 & 7,24 & 0,00 & 7,24 \\
\hline Çeșitli Mal ve Hizmetler & 5,15 & 0,58 & 4,14 & 0,88 & 3,97 & 0,75 & 3,97 \\
\hline
\end{tabular}

Tablo 11: 2013-2017 Döneminde döviz kurları ile fiyat artıșı arasındaki korelasyon

\begin{tabular}{|c|c|c|c|c|c|c|c|}
\hline \multirow[t]{3}{*}{ SEPET } & & \multicolumn{2}{|c|}{ USD } & \multicolumn{2}{|c|}{ EURO } & \multicolumn{2}{|c|}{ SEPET } \\
\hline & \multicolumn{2}{|c|}{ DOLAR ILE KORELASYON } & \multicolumn{2}{|c|}{ EURO ILE KORELASYON } & \multicolumn{2}{|c|}{ SEPET KUR ILE KORELASYON } & \\
\hline & $\% 51-\% 89$ & \%90 ÜZERI & $\% 51-\% 89$ & \%90 ÜZERi & $\% 51-\% 89$ & \%90 ÜZERi & \\
\hline TOPLAM & & 24,22 & 64,93 & 38,74 & 52,13 & 24,97 & 65,00 \\
\hline Gıda ve Alkolsüz İçecekler & 23,29 & 6,79 & 13,15 & 14,14 & 5,38 & 7,48 & 12,43 \\
\hline Alkollü İçecekler ve Tütün & 4,23 & 0,00 & 4,23 & 0,00 & 4,23 & 0,00 & 4,23 \\
\hline Giyim ve Ayakkabı & 7,24 & 4,19 & 2,01 & 4,99 & 1,09 & 4,74 & 1,46 \\
\hline Konut & 15,16 & 4,34 & 9,00 & 6,30 & 7,05 & 4,34 & 9,00 \\
\hline Ev Eșyası & 8,33 & 1,72 & 6,14 & 4,18 & 3,68 & 2,29 & 5,57 \\
\hline Sağlık & 2,58 & 0,00 & 1,97 & 0,46 & 1,50 & 0,00 & 1,97 \\
\hline Ulaștırma & 16,78 & 0,83 & 11,50 & 2,09 & 11,64 & 0,01 & 12,31 \\
\hline Haberleșme & 3,69 & 0,24 & 2,91 & 3,06 & 0,09 & 2,37 & 0,79 \\
\hline Eğlence ve Kültür & 3,29 & 0,61 & 2,01 & 0,92 & 1,69 & 0,62 & 2,00 \\
\hline Eğitim & 2,40 & 0,00 & 1,47 & 0,00 & 1,47 & 0,00 & 1,47 \\
\hline Lokanta ve Oteller & 7,86 & 1,07 & 6,17 & 1,07 & 6,17 & 1,07 & 6,17 \\
\hline Çeșitli Mal ve Hizmetler & 5,15 & 0,46 & 4,37 & 1,07 & 3,76 & 0,99 & 3,85 \\
\hline
\end{tabular}


Tablo 12: 2013-2017 Döneminde döviz kurları ile bir sonraki dönem (t+1) fiyat artıșı arasındaki korelasyon

\begin{tabular}{|c|c|c|c|c|c|c|c|}
\hline \multirow[t]{3}{*}{ SEPET $(t+1)$} & & \multicolumn{2}{|c|}{ USD } & \multicolumn{2}{|c|}{ EURO } & \multicolumn{2}{|l|}{ SEPET } \\
\hline & \multicolumn{2}{|c|}{ DOLAR ILE KORELASYON } & \multicolumn{2}{|c|}{ EURO ILE KORELASYON } & \multicolumn{2}{|c|}{ SEPET KUR ILE KORELASYON } & \\
\hline & $\% 51-\% 89$ & \%90 ÜZERi & $\% 51-\% 89$ & \%90 ÜZERi & $\% 51-\% 89$ & \%90 ÜZERi & \\
\hline TOPLAM & & 22,42 & 68,10 & 36,05 & 54,90 & 25,35 & 64,56 \\
\hline Gıda ve Alkolsüz İçecekler & 23,29 & 7,85 & 13,02 & 11,99 & 7,60 & 7,54 & 12,30 \\
\hline Alkollü İçecekler ve Tütün & 4,23 & 0,00 & 4,23 & 0,00 & 4,23 & 0,00 & 4,23 \\
\hline Giyim ve Ayakkabı & 7,24 & 4,34 & 1,46 & 4,90 & 1,18 & 4,74 & 1,46 \\
\hline Konut & 15,16 & 4,34 & 9,00 & 6,27 & 7,08 & 4,34 & 9,00 \\
\hline Ev Eșyası & 8,33 & 1,89 & 5,97 & 4,12 & 3,74 & 2,44 & 5,42 \\
\hline Sağlık & 2,58 & 0,00 & 1,97 & 0,46 & 1,50 & 0,00 & 1,97 \\
\hline Ulaștırma & 16,78 & 0,65 & 11,68 & 1,90 & 11,83 & 0,39 & 11,93 \\
\hline Haberleșme & 3,69 & 0,29 & 2,86 & 3,06 & 0,09 & 2,32 & 0,83 \\
\hline Eğlence ve Külłür & 3,29 & 0,61 & 2,01 & 0,82 & 1,80 & 0,55 & 2,06 \\
\hline Eğitim & 2,40 & 0,00 & 1,47 & 0,00 & 1,47 & 0,00 & 1,47 \\
\hline Lokanta ve Oteller & 7,86 & 1,07 & 6,17 & 1,07 & 6,17 & 1,07 & 6,17 \\
\hline Çeșitli Mal ve Hizmetler & 5,15 & 0,40 & 4,43 & 1,06 & 3,78 & 0,89 & 3,94 \\
\hline
\end{tabular}

Tablo 13: 2013-2017 Döneminde döviz kurları ile üç dönem sonraki (t+3) fiyat artıșı arasındaki korelasyon

\begin{tabular}{|c|c|c|c|c|c|c|c|}
\hline \multirow[t]{3}{*}{ SEPET $(t+3)$} & & \multicolumn{2}{|c|}{ USD } & \multicolumn{2}{|c|}{ EURO } & \multicolumn{2}{|l|}{ SEPET } \\
\hline & \multicolumn{2}{|c|}{ DOLAR ILE KORELASYON } & \multicolumn{2}{|c|}{ EURO ILE KORELASYON } & \multicolumn{2}{|c|}{ SEPET KUR ILE KORELASYON } & \\
\hline & $\% 51-\% 89$ & \%90 ÜZERi & $\% 51-\% 89$ & \%90 ÜZERi & $\% 51-\% 89$ & \%90 ÜZERi & \\
\hline TOPLAM & & 23,27 & 67,25 & 40,42 & 52,29 & 27,47 & 64,07 \\
\hline Gıda ve Alkolsüz içecekler & 23,29 & 8,22 & 12,70 & 11,26 & 8,87 & 9,71 & 10,88 \\
\hline Alkollü İçecekler ve Tütün & 4,23 & 0,00 & 4,23 & 3,87 & 0,36 & 0,00 & 4,23 \\
\hline Giyim ve Ayakkabı & 7,24 & 3,40 & 2,20 & 4,44 & 1,26 & 3,50 & 2,20 \\
\hline Konut & 15,16 & 3,51 & 9,84 & 6,27 & 7,08 & 4,34 & 9,00 \\
\hline Ev Eșyası & 8,33 & 1,74 & 6,12 & 3,91 & 3,95 & 2,21 & 5,65 \\
\hline Sağlık & 2,58 & 0,00 & 1,97 & 0,46 & 1,50 & 0,00 & 1,97 \\
\hline Ulaștırma & 16,78 & 0,65 & 11,68 & 3,71 & 11,79 & 1,80 & 11,93 \\
\hline Haberleșme & 3,69 & 2,37 & 0,79 & 3,06 & 0,09 & 2,32 & 0,83 \\
\hline Eğlence ve Kültür & 3,29 & 0,68 & 2,07 & 0,60 & 2,01 & 0,69 & 2,06 \\
\hline Eğitim & 2,40 & 0,00 & 1,47 & 0,00 & 1,47 & 0,00 & 1,47 \\
\hline Lokanta ve Oteller & 7,86 & 1,07 & 6,17 & 1,07 & 6,17 & 1,07 & 6,17 \\
\hline Çeșitli Mal ve Hizmetler & 5,15 & 0,74 & 4,09 & 1,03 & 3,64 & 0,80 & 4,04 \\
\hline
\end{tabular}


Tablo 14: 2017-2019:04 Döneminde döviz kurları ile fiyat artıșı arasındaki korelasyon

\begin{tabular}{|c|c|c|c|c|c|c|c|}
\hline \multirow[t]{3}{*}{ SEPET } & & \multicolumn{2}{|c|}{ USD } & \multicolumn{2}{|c|}{ EURO } & \multicolumn{2}{|c|}{ SEPET } \\
\hline & \multicolumn{2}{|c|}{ DOLAR ILE KORELASYON } & \multicolumn{2}{|c|}{ EURO ILE KORELASYON } & \multicolumn{2}{|c|}{ SEPET KUR ILE KORELASYON } & \\
\hline & $\% 51-\% 89$ & \%90 ÜZERI & $\% 51-\% 89$ & \%90 ÜZERI & $\% 51-\% 89$ & \%90 ÜZERi & \\
\hline TOPLAM & & 73,18 & 18,45 & 71,02 & 19,66 & 73,91 & 17,46 \\
\hline Gıda ve Alkolsüz İçecekler & 23,29 & 20,18 & 0,12 & 20,49 & 0,25 & 20,04 & 0,25 \\
\hline Alkollü İçecekler ve Tütün & 4,23 & 0,36 & 0,00 & 0,36 & 0,00 & 0,36 & 0,00 \\
\hline Giyim ve Ayakkabı & 7,24 & 3,38 & 0,13 & 4,13 & 0,08 & 3,45 & 0,13 \\
\hline Konut & 15,16 & 15,16 & 0,00 & 15,16 & 0,00 & 15,16 & 0,00 \\
\hline Ev Eșyası & 8,33 & 7,03 & 0,94 & 6,47 & 1,50 & 6,39 & 1,58 \\
\hline Sağlık & 2,58 & 2,58 & 0,00 & 2,58 & 0,00 & 2,58 & 0,00 \\
\hline Ulaștırma & 16,78 & 5,88 & 10,87 & 5,24 & 11,51 & 5,81 & 10,95 \\
\hline Haberleșme & 3,69 & 3,45 & 0,00 & 1,37 & 0,00 & 3,50 & 0,00 \\
\hline Eğlence ve Kültür & 3,29 & 2,40 & 0,24 & 2,64 & 0,20 & 2,40 & 0,24 \\
\hline Eğitim & 2,40 & 2,40 & 0,00 & 1,72 & 0,67 & 2,40 & 0,00 \\
\hline Lokanta ve Oteller & 7,86 & 1,07 & 6,17 & 1,07 & 6,17 & 1,07 & 6,17 \\
\hline Çeșitli Mal ve Hizmetler & 5,15 & 0,46 & 4,37 & 1,07 & 3,76 & 0,99 & 3,85 \\
\hline
\end{tabular}

Tablo 15: 2017-2019:04 Döneminde döviz kurları ile bir sonraki dönem (t+1) fiyat artıșı arasındaki korelasyon

\begin{tabular}{|l|c|c|c|c|c|c|c|c|}
\hline & & \multicolumn{2}{|c|}{ USD } & \multicolumn{3}{c|}{ EURO } & \multicolumn{3}{c|}{ SEPET } \\
\hline & DOLAR iLE KORELASYON & EURO iLE KORELASYON & SEPET KUR ILE KORELASYON & \\
\hline & \%51-\%89 & \%90 ÜZERi & \%51-\%89 & \%90 ÜZERi & $\% 51-\% 89$ & $\% 90$ ÜZERi & \\
\hline TOPLAM & & 56,15 & 35,92 & 49,04 & 41,56 & 54,40 & 37,79 \\
\hline Gıda ve Alkolsüz içecekler & $\mathbf{2 3 , 2 9}$ & 16,37 & 3,90 & 15,03 & 5,57 & 14,88 & 5,27 \\
\hline Alkollü İçecekler ve Tütün & $\mathbf{4 , 2 3}$ & 0,36 & 0,00 & 0,36 & 0,00 & 0,36 & 0,00 \\
\hline Giyim ve Ayakkabı & $\mathbf{7 , 2 4}$ & 3,82 & 0,31 & 3,98 & 0,31 & 3,69 & 0,51 \\
\hline Konut & $\mathbf{1 5 , 1 6}$ & 7,53 & 7,63 & 9,10 & 6,06 & 9,10 & 6,06 \\
\hline Ev Eșyası & $\mathbf{8 , 3 3}$ & 3,94 & 4,03 & 3,83 & 4,14 & 3,61 & 4,36 \\
\hline Sağlık & $\mathbf{2 , 5 8}$ & 2,58 & 0,00 & 2,12 & 0,46 & 2,58 & 0,00 \\
\hline Ulaștırma & $\mathbf{1 6 , 7 8}$ & 5,10 & 11,68 & 2,44 & 14,35 & 5,10 & 11,68 \\
\hline Haberleșme & $\mathbf{3 , 6 9}$ & 3,50 & 0,00 & 0,63 & 0,74 & 3,50 & 0,00 \\
\hline Eğlence ve Kültür & $\mathbf{3 , 2 9}$ & 1,66 & 0,94 & 1,69 & 0,93 & 1,64 & 0,96 \\
\hline Eğitim & $\mathbf{2 , 4 0}$ & 2,40 & 0,00 & 2,40 & 0,00 & 2,40 & 0,00 \\
\hline Lokanta ve Oteller & $\mathbf{7 , 8 6}$ & 2,61 & 4,26 & 1,81 & 5,06 & 1,81 & 5,06 \\
\hline Çeșitli Mal ve Hizmetler & $\mathbf{5 , 1 5}$ & 2,84 & 1,97 & 2,84 & 1,98 & 2,90 & 1,91 \\
\hline
\end{tabular}


Tablo 16: 2017-2019:04 Döneminde döviz kurları ile üç dönem sonraki (t+3) fiyat artıșı arasındaki korelasyon

\begin{tabular}{|c|c|c|c|c|c|c|c|}
\hline \multirow[t]{3}{*}{ SEPET $(t+3)$} & & \multicolumn{2}{|c|}{ USD } & \multicolumn{2}{|c|}{ EURO } & \multicolumn{2}{|c|}{ SEPET } \\
\hline & \multicolumn{2}{|c|}{ DOLAR ILE KORELASYON } & \multicolumn{2}{|c|}{ EURO ILE KORELASYON } & \multicolumn{2}{|c|}{ SEPET KUR ILE KORELASYON } & \\
\hline & $\% 51-\% 89$ & \%90 ÜZERI & $\% 51-\% 89$ & \%90 ÜZERI & $\% 51-\% 89$ & \%90 ÜZERI & \\
\hline TOPLAM & & 69,60 & 19,56 & 59,36 & 29,97 & 62,75 & 26,67 \\
\hline Gıda ve Alkolsüz İçecekler & 23,29 & 15,49 & 3,45 & 11,94 & 6,88 & 12,55 & 6,51 \\
\hline Alkollü İçecekler ve Tütün & 4,23 & 0,36 & 0,00 & 0,36 & 0,00 & 0,36 & 0,00 \\
\hline Giyim ve Ayakkabı & 7,24 & 3,22 & 0,53 & 2,55 & 1,27 & 2,69 & 1,06 \\
\hline Konut & 15,16 & 7,53 & 7,63 & 7,29 & 7,87 & 7,29 & 7,87 \\
\hline Ev Eșyası & 8,33 & 4,38 & 2,92 & 3,96 & 3,42 & 3,24 & 4,06 \\
\hline Sağlık & 2,58 & 2,38 & 0,20 & 1,96 & 0,62 & 2,30 & 0,28 \\
\hline Ulaștırma & 16,78 & 16,29 & 0,50 & 16,07 & 0,72 & 16,07 & 0,72 \\
\hline Haberleșme & 3,69 & 2,96 & 0,00 & 2,96 & 0,00 & 2,96 & 0,00 \\
\hline Eğlence ve Kültür & 3,29 & 2,09 & 0,36 & 1,61 & 0,98 & 1,61 & 0,98 \\
\hline Eğitim & 2,40 & 2,40 & 0,00 & 2,40 & 0,00 & 2,40 & 0,00 \\
\hline Lokanta ve Oteller & 7,86 & 6,55 & 0,32 & 2,26 & 4,61 & 5,37 & 1,50 \\
\hline Çeșitli Mal ve Hizmetler & 5,15 & 3,06 & 1,75 & 2,96 & 1,85 & 2,96 & 1,85 \\
\hline
\end{tabular}


